\title{
Hemichannels Are Required for Amyloid $\beta$-Peptide-Induced Degranulation and Are Activated in Brain Mast Cells of APPswe/PS1dE9 Mice
}

\author{
Paloma A. Harcha, ${ }^{1,2}$ Aníbal Vargas, ${ }^{1}$ Chenju Yi, ${ }^{3,4,5}$ Annette A. Koulakoff, ${ }^{3,4,5}$ Christian Giaume, ${ }^{3,4,5}$ and Juan C. Sáez ${ }^{1,2}$ \\ ${ }^{1}$ Departamento de Fisiología, Pontificia Universidad Catülica de Chile, Santiago, Chile, ${ }^{2}$ Instituto Milenio, Centro Interdisciplinario de Neurociencias de \\ Valparaíso, Valparaíso, Chile, ${ }^{3}$ Collège de France, Center for Interdisciplinary Research in Biology/Centre National de la Recherche Scientifique, Unité Mixte \\ de Recherche 7241/Institut National de la Santé et de la Recherche Médicale U1050, 75231 Paris Cedex 05, France, ${ }^{4}$ University Pierre et Marie Curie, 75005 \\ Paris, France, and ${ }^{5}$ MEMOLIFE Laboratory of Excellence and Paris Science Lettre Research University, 75005 Paris, France
}

Mast cells (MCs) store an array of proinflammatory mediators in secretory granules that are rapidly released upon activation by diverse conditions including amyloid beta $(\mathrm{A} \beta)$ peptides. In the present work, we found a rapid degranulation of cultured MCs through a pannexin1 hemichannel (Panx1 HC)-dependent mechanism induced by $\mathrm{A} \beta_{25-35}$ peptide. Accordingly, $\mathrm{A} \beta_{25-35}$ peptide also increased membrane current and permeability, as well as intracellular $\mathrm{Ca}^{2+}$ signal, mainly via Panx1 HCs because all of these responses were drastically inhibited by Panx1 HC blockers and absent in the MCs of Panx ${ }^{-1-}$ mice. Moreover, in acute coronal brain slices of control mice, $\mathrm{A} \beta_{25-35}$ peptide promoted both connexin $43(\mathrm{Cx} 43)$ - and Panx1 HC-dependent MC dye uptake and histamine release, responses that were only Cx43 HC dependent in Panx $1^{-1-}$ mice. Because MCs have been found close to amyloid plaques of patients with Alzheimer's disease (AD), their distribution in brain slices of APPswe/PS1dE9 mice, a murine model of AD, was also investigated. The number of MCs in hippocampal and cortical areas increased drastically even before amyloid plaque deposits became evident. Therefore, MCs might act as early sensors of amyloid peptide and recruit other cells to the neuroinflammatory response, thus playing a critical role in the onset and progression of $\mathrm{AD}$.

Key words: Alzheimer's disease; amyloid peptide; degranulation; hemichannels; mast cells

\section{Introduction}

In the brain, mast cells (MCs) are found mainly in the meningeal layers and within the cerebral parenchyma close to the blood vessels lying between the blood-brain barrier and astrocyte endfeet (Silver et al., 1996; Khalil et al., 2007). MCs contain an array of proinflammatory mediators (e.g., histamine, ATP, cytokines, leukotrienes, and proteases) stored in secretory granules and they rapidly release their content the extracellular milieu upon activation (Metcalfe et al., 1997). MC degranulation can be induced by

Received Sept. 2, 2014; revised May 5, 2015; accepted May 21, 2015.

Author contributions: P.A.H., A.A.K., C.G., and J.C.S. designed research;P.A.H., A.V., and C.Y. performed research; A.A.K., C.G., and J.C.S. contributed unpublished reagents/analytic tools; P.A.H. and A.V. analyzed data; P.A.H., A.V., C.Y., A.A.K., C.G., and J.C.S. wrote the paper.

This work was supported by Comisión de Política Económica y Social - Comisión Nacional de Investigación Científica y Tecnológica (C.G. and J.C.S.), Fondo Nacional de Desarrollo Científico y Tecnológico 1150291 (J.C.S.), Chilean Science Millennium Institute (Grant P09-022-F to J.C.S.), Fondo de Fomento al Desarrollo Científico y Tecnológico D0711086 (J.C.S.), and the Caisse de retraite et de prévoyance des clercs et employés de notaires, Ligue Européenne Contre la Maladie d'Alzheimer, and France Alzheimer (C.G.). These data were presented as partial fulfillment of the thesis of Paloma Harcha in the doctoral program in Physiological Sciences of Pontificia Universidad Católica de Chile.

The authors declare no competing financial interests.

Correspondence should be addressed to either of the following: Paloma Harcha, Departamento de Fisiología, Pontificia Universidad Catülica de Chile, Alameda 340, Santiago, Chile, E-mail: paharcha@gmail.com; or Juan C. Sáez, Departamento de Fisiología, Facultad de Ciencias Biológicas, Pontificia Universidad Católica de Chile, Santiago, Chile, E-mail: jsaez@bio.puc.cl.

DOI:10.1523/JNEUROSCI.3686-14.2015

Copyright $\odot 2015$ the authors $\quad 0270-6474 / 15 / 359526-13 \$ 15.00 / 0$ a number of agents including amyloid peptides (Niederhoffer et al., 2009). These features, together with their strategic localization demonstrate that MCs can initiate and/or modulate different inflammatory responses.

Migration and activation of MCs at sites of injury occur in various neurodegenerative disorders (Secor et al., 2000; Graves et al., 2004; Lozada et al., 2005; Strbian et al., 2006; Fiala et al., 2010; Sayed et al., 2011). In postmortem studies of Alzheimer's disease (AD) patients, MCs have also been found close to amyloid plaque lesions in different brain regions (Maslinska et al., 2007), but their involvement in the onset and/or progression of the disease remains unknown.

In cultured MCs, amyloid beta $(\mathrm{A} \beta)$ peptides $\left(\mathrm{A} \beta_{1-40}\right.$ and $\mathrm{A} \beta_{1-42}$ ) induce a rapid degranulation response (Niederhoffer et al., 2009). This response is mediated through the membrane complex formed by CD47 receptor, $\beta_{1}$ integrin subunit, and $G_{i}$ protein (Niederhoffer et al., 2009). Activation of this complex leads to a $\mathrm{Ca}^{2+}$ influx (Sick et al., 2009) that is essential for MC degranulation. Several membrane channels permeable to $\mathrm{Ca}^{2+}$ have been proposed to participate in this $\mathrm{Ca}^{2+}$ influx (Ma and Beaven, 2011), particularly calcium release activated channels (CRAC) and store-operated $\mathrm{Ca}^{2+}$ channels (Ma and Beaven, 2011), but the possible participation of hemichannels (HCs) has not been evaluated. Because HCs are membrane pores permeable to $\mathrm{Ca}^{2+}$ (Vanden Abeele et al., 2006; Sánchez et al., 2009; 
Schalper et al., 2010; Ishikawa et al., 2011; Fiori et al., 2012) and their critical role in inflammatory process of other cell types or tissues has been demonstrated (Silverman et al., 2009; Cea et al., 2013; Makarenkova and Shestopalov, 2014), we decided to investigate whether MCs express functional HCs and if they participate in the $\mathrm{MC}$ response induced by a toxic $\mathrm{A} \beta$ peptide. $\mathrm{HCs}$ are nonselective membrane channels formed by connexins (Cxs) or pannexins (Panxs) (Bruzzone et al., 2003; Sáez et al., 2005). Although the formation of a Panx gap junction is still a matter of controversy (Sosinsky et al., 2011), in the present work, the term HCs will be used for either Cxs or Panxs. In mammals, there are 21 and 3 members that constitute the $\mathrm{Cx}$ and Panx family, respectively (Panchin et al., 2000). In MCs, Cx43 and Cx32 have been detected (Vliagoftis et al., 1999) but the expression of Panxs has yet to be examined.

We found that acute treatment of cultured MCs with $\mathrm{A} \beta_{25-35}$ peptide activates Panx1 HCs, which mediate $\mathrm{Ca}^{2+}$ influx required for the degranulation response. Brain MCs showed increased Panx1 and Cx43 HC activity after acute treatment with $\mathrm{A} \beta_{25-35}$ peptide, which was directly associated with enhanced histamine release. Moreover, the MC population was drastically increased in the cortex and hippocampus before the onset of amyloid plaque formation and showed increased Panxl and Cx43 HC activity in APPswe/PS1dE9 mice, a murine model of AD (Koulakoff et al., 2012). Therefore, we suggest that MCs are one of the first brain cells that sense amyloid peptides, being the HCs essential for the degranulation response, and thus may play a critical role in the onset and progression of $\mathrm{AD}$.

\section{Materials and Methods}

Chemicals. RPMI 1640 and IMDM culture medium, penicillin, streptomycin, and fetal bovine serum (FBS) were obtained from Invitrogen. 2-Mercaptoethanol, probenecid ( $\mathrm{Pbc}$ ), carbenoxolone (Cbx), 4', 6-diamidino-2-phenylindoleethidium (DAPI), and ethidium (Etd) bromide were acquired from Sigma-Aldrich. Halt protease inhibitor singleuse mixture and M-PER solution were purchased from Thermo Scientific. Protein assay was obtained from Bio-Rad. SuperSignal kit and anti-rabbit antibody conjugated to horseradish peroxidase were purchased from Pierce. Peptides $A \beta_{25-35}$ and $A \beta_{35-25}$ were supplied by Bachem and GenScript and peptide $\mathrm{A} \beta_{1-42}$ was purchased from Phoenix Biotech. ${ }^{10} \mathrm{Panx} 1$ mimetic (WRQAAFVDSY) and scrambled (RAFDWAYVQS) peptides were purchased from SBSBIO. Fluoromount $G$ was obtained from Electron Microscopy Sciences.

Antibodies. Rabbit polyclonal anti-A $\beta$ antibody was purchased from BioSource, anti-mouse CD16/CD32 (Fc-Block, 1:150) antibody was obtained from BD Pharmingen, rat anti-mouse CD117 antibody conjugated to FITC (1:75) was supplied by eBioscience, and goat anti-rabbit conjugated to Alexa Fluor 555 (1:4000) was obtained from Invitrogen. A polyclonal rabbit anti-Panxl antibody described previously (Riquelme et al., 2013) was used.

Animals. Animal experimentation was performed in accordance with the National Institutes of Health's Guide for the Care and Use of Laboratory Animals and the European Community Council directives of November 24th 1986 (86/609/EEC) and received the approval of the Committee of Bioethics and Biosecurity from the Pontificia Universidad Católica de Chile CBB 132/2012. Double-transgenic APPswe/PS1dE9 mice were obtained from The Jackson Laboratory and were bred in the Center for Interdisciplinary Research in Biology facility (Jankowsky et al., 2001). Panx1 knock-out (Panx1 $\left.{ }^{-/-}\right)$mice were generated as described previously (Anselmi et al., 2008; Bargiotas et al., 2011) and were kindly donated by Dr. Hanna Monyer (University of Heilderberg, Germany). Wild-type (WT) C57BL/6 mice were used as control animals. All animals were killed by cervical dislocation.

Isolation and differentiation of MCs. Bone marrow MCs (BMMCs) were prepared as described previously (Jensen et al., 2006). In brief, bone marrow precursor cells from tibia and femur bones of 2-month-old WT and Panx1 ${ }^{-1-}$ mice were flushed out to a RPMI 1640 medium, supplemented with 20\% WEHI conditioned medium, 10\% FBS, $50 \mu \mathrm{M}$ 2-mercaptoethanol, and $100 \mathrm{units} / \mathrm{ml}$ penicillin and streptomycin. Precursors were plated in Sarstedt T25 plastic flasks $\left(1.25 \times 10^{4} \mathrm{cells} / \mathrm{ml}\right.$ in $10 \mathrm{ml})$. The medium was changed twice a week. After 4 weeks, cell suspensions were collected and used.

$\mathrm{HeLa}$ cells. Experiments were performed in HeLa cells stably transfected with mouse Cx43 (HeLa-Cx43 cells) and Panxl (HeLa-Panxl cells). HeLa Panx1 was kindly donated by Dr. Felixas Bukaukas (Department of Neuroscience, Albert Einstein College of Medicine, Bronx, NY). Cells were cultured in DMEM supplemented with $10 \% \mathrm{FBS}$ and $50 \mathrm{U} / \mathrm{ml}$ penicillin and streptomycin, $\mathrm{pH}$ 7.4. To maintain stable transfections, $\mathrm{HeLa} \mathrm{Cx} 43$ cells were maintained with $0.01 \mathrm{mg} / \mathrm{ml}$ puromycin and HeLa Panx1 in $1 \mathrm{mg} / \mathrm{ml} \mathrm{G} 418$ (Invitrogen). All cells were kept at $37^{\circ} \mathrm{C}$ in a $5 \%$ $\mathrm{CO}_{2} / 95 \%$ air atmosphere at nearly $100 \%$ relative humidity.

Western blot analysis. BMMCs were washed with PBS and centrifuged for $5 \mathrm{~min}$ at $500 \times \mathrm{g}$. Cells were then resuspended in Halt protease inhibitor mixture (Thermo Scientific). Protein content was determined by using the Bradford's method from Bio-Rad. Samples of $60 \mu \mathrm{g}$ of total protein were mixed with Laemmli buffer, immediately resolved in $10 \%$ SDS-PAGE gels, and transferred to PVDF membranes. Nonspecific protein binding was blocked by $1 \mathrm{~h}$ incubation of nitrocellulose sheets in PBS-BLOTTO ( $5 \%$ nonfat milk in PBS). Overnight incubation of blots at $4^{\circ} \mathrm{C}$ with rabbit anti-Panx 1 antibody was followed by three PBS washes. Blots were then incubated for $1 \mathrm{~h}$ at room temperature with secondary anti-rabbit IgG antibody conjugated to HRP. Antigen-antibody complexes were detected using the SuperSignal kit according to the manufacturer's instructions (Pierce).

Degranulation assays. Because toluidine blue (TB) is an alkaline dye retained by proteoglycans in secretion granules (Shukla et al., 2006), we used it as an indicator of MC degranulation. Cells were first seeded on poly-L-lysine $(0.05 \% \mathrm{w} / \mathrm{v})$-coated glass coverslips for $15 \mathrm{~min}$ to allow their adhesion. Then, cells were incubated in saline solution containing $1.8 \mathrm{~mm}$ TB for $10 \mathrm{~min}$ at room temperature, washed 3 times, and immersed in recording solution for time-lapse imaging. Bright-field images were captured with a Nikon Eclipse Ti inverted microscope every $30 \mathrm{~s}$ $(40 \times)$. The blue staining intensity was quantified with ImageJ version 1.64 and analyzed with GraphPad Prism 5 software.

For histamine quantification, a fluorometric assay based on its stable condensation with $O$-phthalaldehyde (OPT) in an alkaline medium was used (Shore et al., 1959). For quantification in BMMC preparations, 250,000 cells were plated in $200 \mu \mathrm{l}$ of recording Locke's solution containing the following (in mM): $140 \mathrm{NaCl}, 5.4 \mathrm{KCl}, 1.8 \mathrm{CaCl}_{2}, 1 \mathrm{MgCl}_{2}, 5$ D-glucose, and 10 HEPES, $\mathrm{pH} 7.4$, and then treated with $\mathrm{A} \beta_{25-35}$ peptide for $2 \mathrm{~h}$ at room temperature. For histamine release from brain tissue, 300 $\mu \mathrm{m}$ coronal brain slices obtained from adult mice were also treated with $\mathrm{A} \beta_{25-35}$ peptide in bubbling ASCF at room temperature. This extracellular solution was collected $2 \mathrm{~h}$ later. For HC blocker treatments, brain slices were treated for $20 \mathrm{~min}$ with the indicated drugs and then stimulated with $\mathrm{A} \beta_{25-35}$ peptide in presence of $\mathrm{HC}$ blockers (see "Dye uptake in brain slices").

Supernatants of both MC cultures $(200 \mu \mathrm{l})$ and brain slices $(5 \mathrm{ml})$ were collected and mixed with $7.5 \mu \mathrm{M}$ OPT ( $10 \mu \mathrm{l}$ for MCs and $250 \mu \mathrm{l}$ for brain

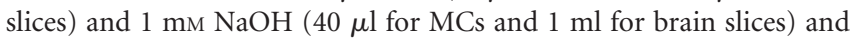
incubated for $4 \mathrm{~min}$ at room temperature. Then, fluorescence was stabilized with $3 \mathrm{~mm} \mathrm{HCl}(20 \mu \mathrm{l}$ was added to MC suspensions and $500 \mu \mathrm{l}$ to brain slices) and measured at $360 \mathrm{~nm}$ (emission $\lambda=450 \mathrm{~nm}$; Shore et al., 1959).

$\mathrm{Ca}^{2+}$ signal. Cells seeded on poly-L-lysine glass coverslips were loaded with $5 \mu \mathrm{M}$ Fura-2AM in RPMI 1640 without serum for $20 \mathrm{~min}$ at room temperature and then washed in recording solution. For intracellular $\mathrm{Ca}^{2+}$ signal measurements, fluorescence was captured every 3 s. Fluorescence intensity ratio was measured at excitation wavelengths of 340 and $380 \mathrm{~nm}$. Images and ratio quantification were performed in a Nikon Eclipse Ti inverted microscope and imaged with NIS Elements software (Nikon).

Time-lapse fluorescence imaging. For time-lapse experiments, MCs seeded on poly-L-lysine-coated glass coverslips were placed in recording solution containing $25 \mu \mathrm{M}$ DAPI or Etd used as HC permeability probes 
because they fluoresce upon binding to intracellular nucleic acids, allowing evaluation of membrane permeability changes via HCs (Schalper et al., 2008). Fluorescence was recorded with the NikonEclipse Ti inverted microscope every $30 \mathrm{~s}$. For image analysis and fluorescence quantification, ImageJ version 1.64 software was used and the data were plotted with GraphPad Prism 5 software.

Electrophysiology. MCs seeded on poly-L-lysine-coated coverslips were first treated with $10 \mu \mathrm{M}$ nocodazole (to avoid MC degranulation and consequent changes in membrane capacitance) for 20 min before transferring to a chamber containing $1 \mathrm{ml}$ of bath solution. Cells were visualized with an inverted microscope (Fluoview IX-70; Olympus) using a $40 \times$ objective. For whole-cell experiments, the bath solution contained the following (in mM): $140 \mathrm{NaCl}, 5.4 \mathrm{CsCl}, 1 \mathrm{MgCl}_{2}, 1.8 \mathrm{CaCl}_{2}, 2 \mathrm{BaCl}_{2}$, and 10 HEPES, $\mathrm{pH}$ 7.4. The pipette solution contained the following (in $\mathrm{mm}): 130 \mathrm{CsCl}, 10 \mathrm{AspNa}, 0.26 \mathrm{CaCl}_{2}, 1 \mathrm{MgCl}_{2}, 2$ EGTA, 7 TEA-Cl, and 5 HEPES, pH 7.2. All recordings were performed at room temperature $\left(21-23^{\circ} \mathrm{C}\right)$. Patch electrodes were made from borosilicate glass capillaries (inner diameter, $0.86 \mathrm{~mm}$; outer diameter, $1.5 \mathrm{~mm}$; A-M Systems) using a Flaming/Brown micropipette puller (P-97; Sutter Instruments) and then tips were polished using a custom-made microforge. Electrode tip resistances were of 20-25 M $\Omega$. Single HC current events were studied with voltage clamp under whole-cell patch-clamp configuration using Axopatch-1D amplifier (Molecular Devices,). Whole-cell currents were filtered at $1 \mathrm{kHz}$ and sampled at $5 \mathrm{kHz}$. Records were processed with a digital low-pass filter of $0.5 \mathrm{kHz}$. Only patches with seal resistance between 1 and 10 G $\Omega$ were recorded. Data acquisition and analysis were performed using pClamp9 (Molecular Devices). Unitary current events at a given holding potential and point-by-point conversion of the current values to conductance were calculated using frequency histograms analyzed by Clampfit. All recordings were performed in isolated cells to preclude current dissipation to adjacent cells via gap junctions.

Immunofluorescence. For brain MC quantification, female mice 2-16 months old were anesthetized and then perfused with PBS. Brains were then rapidly removed and frozen with isopentane. Coronal sections of 20 $\mu \mathrm{m}$ were cut on cryostat and stored at $-80^{\circ} \mathrm{C}$. Sections were then fixed with $4 \%$ paraformaldehyde at room temperature during $20 \mathrm{~min}$. After 3 immersion washes with PBS, sections were incubated in solution A solution $(0.2 \%$ gelatin $/ 1 \%$ Triton $\mathrm{X}-100$ in PBS) for $30 \mathrm{~min}$ at room temperature. Antibodies (anti-Panx1, anti-A $\beta$ antibody, or anti-CD 117 antibodies) were appropriately diluted in solution A supplemented with $10 \%$ NGS. Primary antibodies were incubated overnight at $4^{\circ} \mathrm{C}$. After 3 immersion washes with PBS, sections were incubated with secondary antibodies for $2 \mathrm{~h}$ at room temperature, washed with PBS, and mounted with Fluoromount G. Mosaic images were then acquired on a Leica TCS SP2 laser-scanning spectral confocal microscope.

For BMMC staining, cells were fixed in 4\% paraformaldehyde at room temperature for $20 \mathrm{~min}$. Solution A was used during $30 \mathrm{~min}$. For specific blockade of Fc receptors, cells were incubated for $45 \mathrm{~min}$ in solution $\mathrm{A}$ containing Fc-Block antibodies (1:150) at room temperature. Then, cells were washed twice in PBS and incubated in anti-CD117 conjugated with FITC overnight in solution A at $4^{\circ} \mathrm{C}$. Finally, samples were incubated with DAPI, washed, and mounted with Fluoromount G. Images were examined with a NikonEclipse Ti inverted microscope.

Dye uptake in brain slices. Acute $300 \mu \mathrm{m}$ coronal brain slices were obtained from 3-month-old female WT or Panx1 ${ }^{-1-}$ mice. After decapitation, brains were rapidly isolated and placed in ice-cold slicing solution containing the following (in mM): $27 \mathrm{NaHCO}_{3}, 222$ sucrose, $2.6 \mathrm{KCl}, 1.5 \mathrm{NaH}_{2} \mathrm{PO}_{4}, 0.5 \mathrm{CaCl}_{2}, 7 \mathrm{MgSO}_{4}$, and 0.1 ascorbic acid, and bubbled with $95 \% \mathrm{O}_{2} / 5 \% \mathrm{CO}_{2}$. Brains were then cut using a vibratome (VT 1200; Leica) and stabilized in artificial CSF (ACSF) containing the following (in $\mathrm{mM}$ ): $125 \mathrm{NaCl}, 2.5 \mathrm{KCl}, 25$ glucose, 25 $\mathrm{NaHCO}_{3}, 1.25 \mathrm{NaH}_{2} \mathrm{PO}_{4}, 2 \mathrm{CaCl}_{2}$, and $1 \mathrm{MgCl}_{2}$, and bubbled with $95 \% \mathrm{O}_{2} / 5 \% \mathrm{CO}_{2}$ for $1 \mathrm{~h}$ at room temperature in the presence of $2 \mathrm{~mm}$ pyruvate. After this period, brain slices were incubated in the presence of the different drugs for $20 \mathrm{~min}$ at room temperature in bubbling ASCF. Slices were treated for $2 \mathrm{~h}$ with $10 \mu \mathrm{M}$ amyloid peptide ${ }_{25-35}$, after which time $4 \mu \mathrm{M}$ Etd was added for $10 \mathrm{~min}$ and washed with ASCF. Samples were protected from light and fixed for immunostaining with $4 \%$ paraformaldehyde for $1 \mathrm{~h}$ at $4^{\circ} \mathrm{C}$. After several washes with PBS, slices were incubated with blocking solution $(0.2 \%$ gelatin/1\% Triton X-100 in PBS) for $1 \mathrm{~h}$. Primary antibody CD117 FITC $(1: 75)$ was prepared in blocking solution in the presence of NGS $(10 \%)$ and incubated at room temperature for $3 \mathrm{~h}$. Samples were washed and mounted with Fluoromount G. Stacks of consecutive 11 images were taken with a confocal laser-scanning microscopy every $0.49 \mu \mathrm{m}$ acquired sequentially with two lasers at 488 and $543 \mathrm{~nm}$ (63×, Fluoview FV1000; Olympus), and $Z$ projections of 22 serial optical sections were then reconstructed with ImageJ software.

For brain MC HC activity evaluation in an $\mathrm{AD}$ mice model, 8-month-old WT and APPswe/PS1dE9 female mice were used. Brain slices were obtained and stabilized as described above and basal Etd uptake was measured in the presence and absence of $\mathrm{HC}$ blockers. Immunostaining of amyloid plaque deposits was performed using rabbit polyclonal anti-A $\beta$ (1:1000), which was incubated together with anti CD117 FITC (1:75) in the blocking solution (10\% NGS) for $3 \mathrm{~h}$ at room temperature. Then, after several washes, slices were incubated with goat anti-rabbit coupled with Alexa Fluor 647 (1:2000) for $2 \mathrm{~h}$ at room temperature. For immunodetection, stacks of consecutive images were acquired in a confocal laser-scanning microscope (SP5; Leica) sequentially with three lasers $(488,561$, and $647 \mathrm{~nm})$ and $Z$ projections were reconstructed with Leica software.

Statistical analysis. All data in this work are presented as mean \pm SEM. For statistical analysis, each condition was compared with its respective control using one-way ANOVA test and significance was determined with a posteriori Tukey's test.

\section{Results \\ BMMCs express Panx1}

Because the expression of Panxs by MCs remains unknown, we evaluated whether they express Panx1, Panx2, and/or Panx3. To this end, we used cultures highly enriched in MCs differentiated from bone marrow precursors obtained from WT and Panx1 ${ }^{-1-}$ mice and recognized by their CD117 reactivity (Jordan et al., 2001; Fig. 1A). PCR analysis of cDNAs obtained from total mRNA extracted from WT MCs showed an amplicon of the expected size (235 bp) for Panx1 (Fig. 1B). In contrast, no PCR products for Panx2 (267 bp) or Panx3 (478 bp) were detected (Fig. 1B). Moreover, the mRNAs of these three Panxs were not detected in MCs obtained from Panx1 ${ }^{-/-}$mice (Fig. $1 B$ ).

\section{A $\boldsymbol{\beta}_{25-35}$ peptide activates Panx1 HCs in MCs}

Because Panx1 forms membrane HCs permeable to ions, we investigated whether these HCs were active under basal conditions and after stimulation with the toxic $\mathrm{A} \beta_{25-35}$ peptide (Pike et al., 1995). This possibility was studied using two complementary approaches: (1) by recording the total membrane current by voltage clamp under whole-cell configuration and (2) by measuring membrane permeability to dyes in time-lapse measurements. We used $\mathrm{A} \beta_{25-35}$ peptide because it has been shown to present similar biophysics properties as the neuritic $\mathrm{A} \beta_{1-42}$ (Shanmugam and Polavarapu, 2004) and is highly neurotoxic (Pike et al., 1995; Orellana et al., 2011).

For studies of membrane currents, MCs were pretreated (20 $\mathrm{min}$ ) with nocodazol to avoid degranulation that could affect the membrane capacitance due to vesicle fusion and internalization. However, the application of $10 \mu \mathrm{M} \mathrm{A} \beta_{25-35}$, but not the inverted peptide, enhanced the membrane current (Fig. $2 A$ ) and this response was not elicited in Panx1 ${ }^{-1-}$ MCs (Fig. $2 A$ ). Unitary current events corresponding to $\sim 417 \mathrm{pS}$ were also identified in WT MCs after treatment with $\mathrm{A} \beta_{25-35}$ peptide (Fig. $2 A$, inset). The slope of the current traces of WT MCs under control conditions or after $\mathrm{A} \beta_{25-35}$ peptide and inverted peptide treatment were $2.4 \pm 0.2 \mathrm{pA} / \mathrm{s}, 7.2 \pm 0.8 \mathrm{pA} / \mathrm{s}$, and $2.4 \pm 0.1 \mathrm{pA} / \mathrm{s}$, respectively $(n=3)$; whereas, in Panx1 ${ }^{-1-}$ MCs under control conditions and after amyloid treatment, the slopes were $1.5 \pm 0.1 \mathrm{pA} / \mathrm{s}$ and $2.2 \pm 0.1 \mathrm{pA} / \mathrm{ms}$, respectively $(n=3$; Fig. $2 B)$. 
A
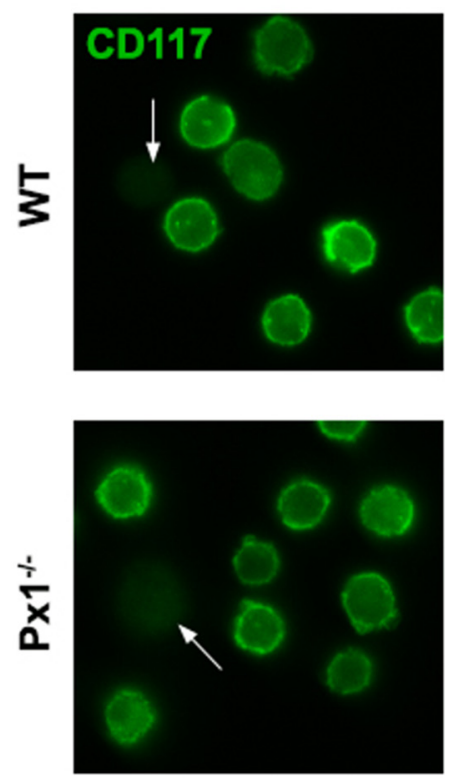
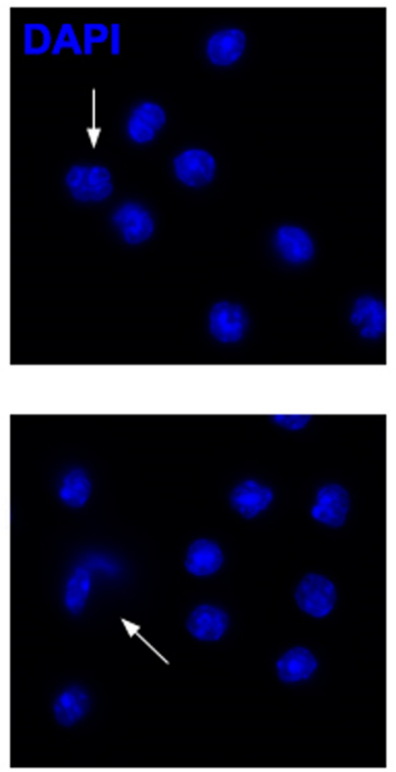

B
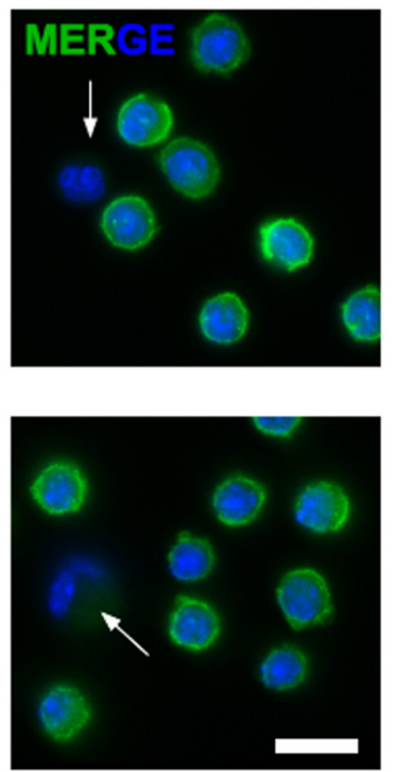

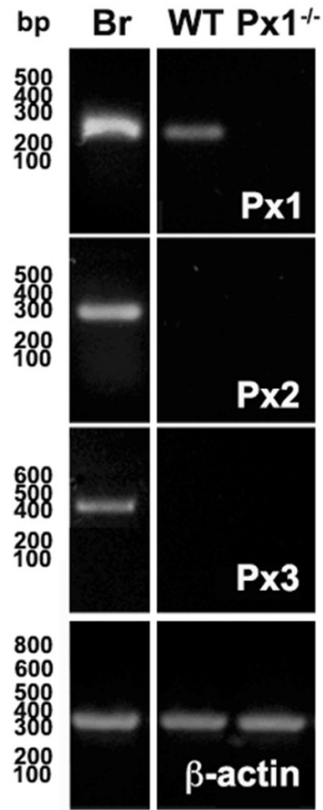

Figure 1. Primary cultures of BMMCs are highly enriched in CD117-positive cells that express Panx1 but not Panx2 or Panx3.A, The MC marker CD117 (green) was evaluated in BMMCs from WT

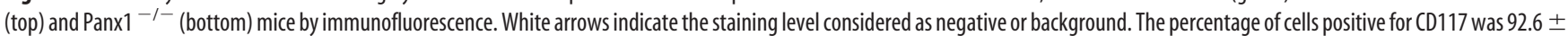
1.2\% for WT and $92.8 \pm 0.9 \%$ for Panx1 ${ }^{-1-}$ BMMCs $(n=5)$. Scale bar, $20 \mu \mathrm{m}$. B, Total RNA of brain sample (Br) from WT mice was used as positive control for Panx1 (Px1), Panx2 (Px2), and Panx3 (Px3) mRNA analyzed by RT-PCR. An amplicon for Px1, but not for Px2 and Panx3, was detected in total RNA of BMMCs. Relative levels of $\beta$-actin mRNA from each sample were used as a loading control.

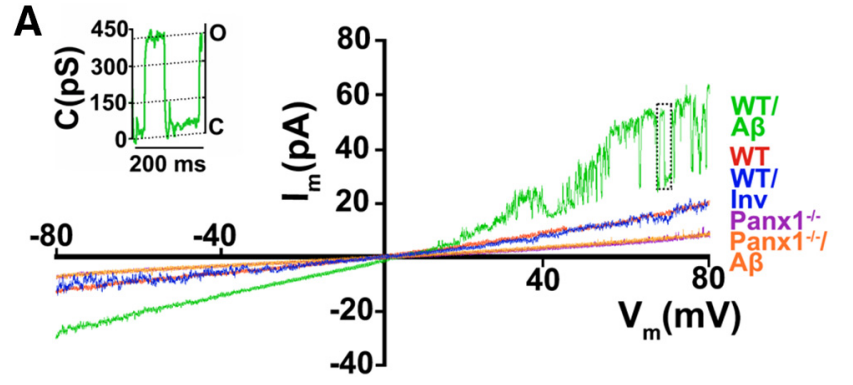

B

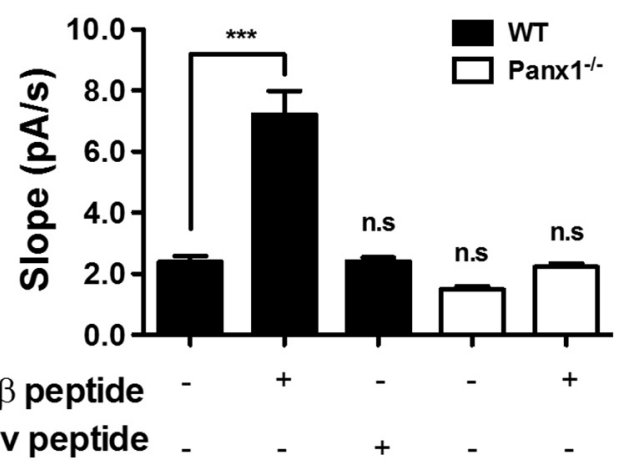

Figure 2. Panx1 is essential for $A \beta_{25-35}$ peptide-induced membrane current in MCs. Membrane currents induced by $10 \mu \mathrm{m} \mathrm{A} \beta_{25-35}$ peptide were measured under voltage clamp using the whole-cell configuration in MCs pretreated for 20 min with $10 \mu$ m nocodazole. $A$, Representative current traces obtained with ramp voltage protocols from -80 to $+80 \mathrm{mV}$ applied during 9 s. Inset, Unitary current events corresponding to $\sim 417 \mathrm{pS}$ were evident in WT MCs treated with $A \beta_{25-35}$ peptide (A $\beta$ peptide). $B$, Quantification of the current trace slope under control conditions and after $A \beta_{25-35}$ peptide or $A \beta_{35-25}$ peptide (Inv peptide) treatment in WT and Panx $1^{-1-}$ MCs. Each value represents the mean \pm SEM $\left(^{* * *} p<0.0005\right.$ ANOVA, Tukey test, n.s.; $n=3$ ).
In time-lapse experiments, $\mathrm{A} \beta_{25-35}$ promoted DAPI uptake. Representative images of DAPI uptake before and after 15 min of $\mathrm{A} \beta_{25-35}$ treatment in WT (top) and Panx1 ${ }^{-/-} \mathrm{MCs}$ (bottom) are shown in Figure $3 A$. The application of $10 \mu \mathrm{M}$ $\mathrm{A} \beta_{25-35}$ rapidly increased DAPI uptake in WT but not in Panx1 ${ }^{-1-}$ MCs (Fig. 3B). In WT MCs, the rate of DAPI uptake determined from the fluorescence intensity over time (normalized to the control value) was significantly higher after $\mathrm{A} \beta_{25-35}$ treatment $\left(2.5 \pm 0.2\right.$-fold, $\left.n=6,{ }^{* *} p<0.0005\right)$, but was not affected after treatment with the inverted peptide $(1.0 \pm 0.2$-fold, n.s., $p>0.05, n=3)$. Moreover, the $\mathrm{A} \beta_{25-35}$ peptide-induced DAPI uptake was prevented by $20 \mathrm{~min}$ of treatment with the following Panx1 HC blockers: $10 \mu \mathrm{M}$ carbenoxolone ( $1.1 \pm 0.1$-fold, n.s. $p>0.05 ; n=3,), 1 \mathrm{~mm}$ probenecid ( $1.0 \pm 0.9$-fold, n.s.; $p>0.05 ; n=3)$, or $200 \mu \mathrm{M}$ ${ }^{10}$ panx 1 peptide $(1.0 \pm 0.9$-fold; $n=3$; Fig. $3 C)$. Additionally, in MCs of Panx $1^{-1-}$ mice, the DAPI uptake rate was affected by neither $\mathrm{A} \beta_{25-35}$ peptide $(0.9 \pm 0.1$-fold, n.s., $p>0.05 ; n=$ 4) nor the inverted peptide $(1.0 \pm 0.1$-fold, n.s., $p>0.05 ; n=$ 4). The effect of carbenoxolone was also tested in Panx $1^{-1-}$ MCs and no significant differences were found in DAPI uptake ( $0.9 \pm 0.1$-fold, n.s., $p>0.05 ; n=4$; Fig. $3 C$, white columns). In addition, we used masitinib, an inhibitor of CD117 tyrosine kinase (Dubreuil et al., 2009) that is known to inhibit the survival, migration, and activation of MCs (Metcalfe et al., 1997). A $\beta_{25-35}$ peptide-induced DAPI uptake was almost completely prevented by masitinib, but the effect of this compound was due neither to $\mathrm{Cx} 43$ nor Panx1 HC inhibition because HeLa transfectants treated with conditions that increase the open probability of each HC type (Bao et al., 2004; Schalper et al., 2008) was not affected by acute application of $10 \mu \mathrm{M}$ masitinib (Fig. 3D).

Notably, treatment with $\mathrm{A} \beta_{25-35}$ peptide did not promote Etd uptake (Fig. 3E), another classic dye used in the study of HC 
A
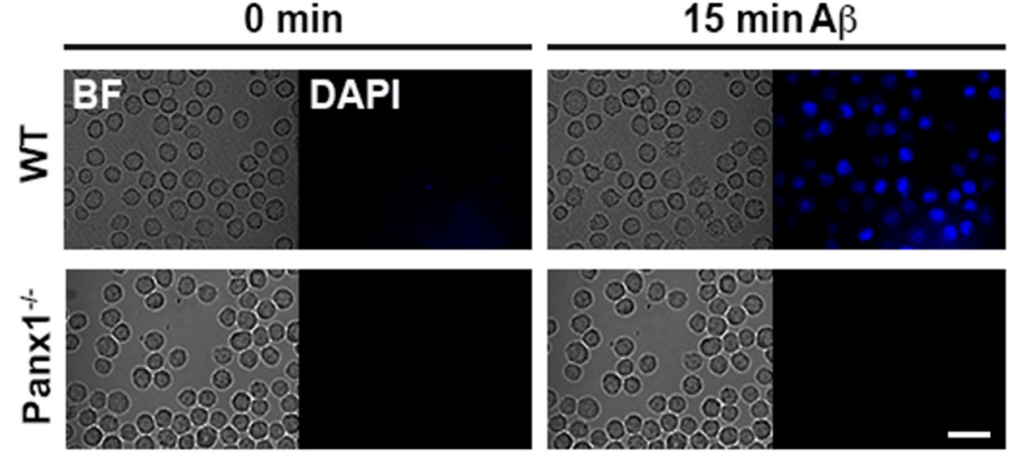

C

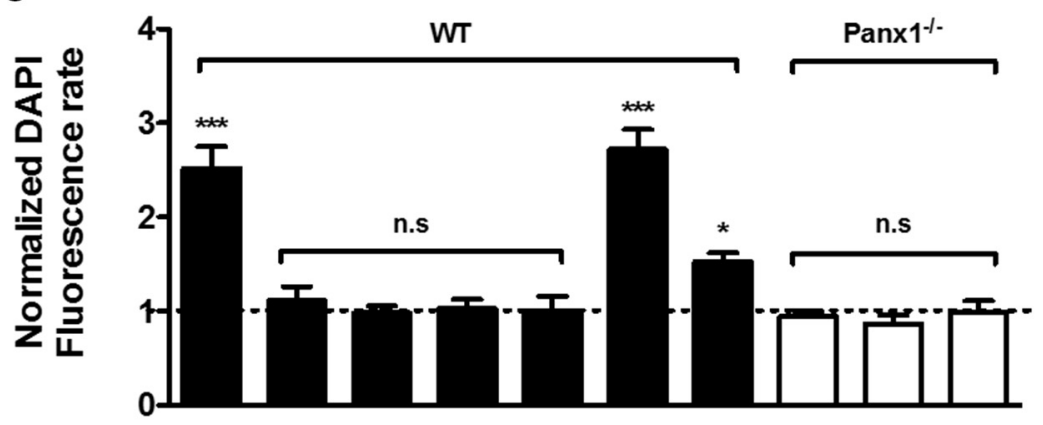

B

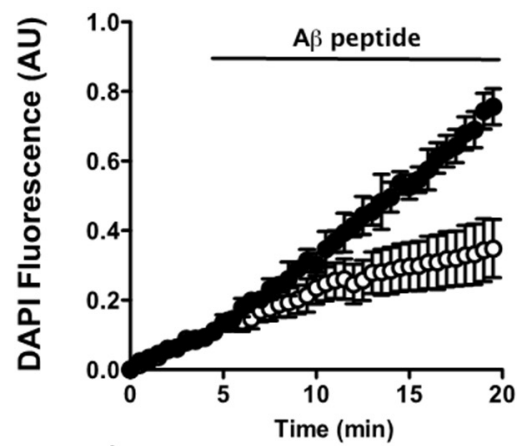

D

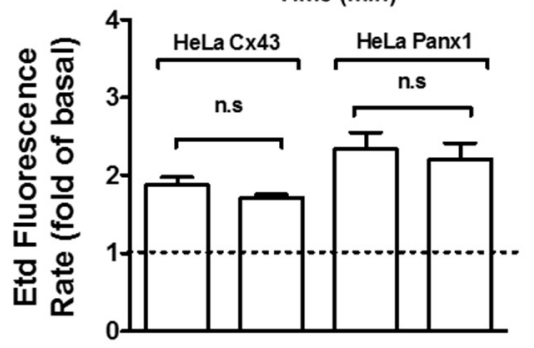

E

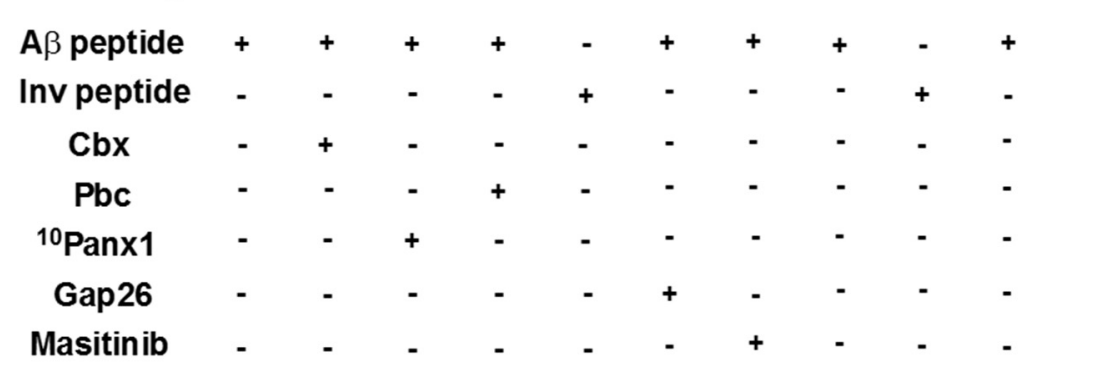

Figure 3. The $A \beta_{25-35}$ peptide enhances DAPI uptake in MCs in a Panx1 HC-dependent manner. $A$, Representative bright-field (BF) and fluorescent view of the same field (DAPI) of MCs from WT and Panx 1 knock-out $\left(\operatorname{Panx}^{-1-}{ }^{-1}\right.$ ) mice at time $0(0 \mathrm{~min})$ and after 15 min treatment with $10 \mu \mathrm{m} \mathrm{A} \beta_{25-35}$ peptide $(\mathrm{A} \beta)$. Scale bar, $20 \mu \mathrm{m}$. $\boldsymbol{B}$, Time lapse of DAPl uptake under basal condition $(0-5$ $\mathrm{min}$ ) and after $10 \mu \mathrm{M} \mathrm{A} \beta_{25-35}$ peptide stimulation for $15 \mathrm{~min}$ (5-20 min) in WT (black circles) and Panx1 ${ }^{-1-}$ (white circles) MCs. C, Normalized quantification of DAPI uptake rate after A $\beta_{25-35}$ peptide $(n=6)$ or inverted peptide $(n=3)$ treatment and after pretreatment with blockers of HCs formed by Panx 1: $1 \mathrm{~mm}$ probenecid (Pbc), $10 \mu \mathrm{m}$ carbenoxolone (Cbx), or $200 \mu \mathrm{M}{ }^{10} \mathrm{Panx} 1$. Each value represents the mean \pm SEM $\left({ }^{* * *} p<0.0005\right.$ ANOVA Tukey test. n.s.; $n=3$ for HC blockers in WT MCs and $n=4$ for the same treatments in Panx $1^{-1-}$ MCs). D, Etd uptake through HCs in HeLa cells transfected with Cx43 or Panx1. The open probability of HCs was induced with a DCFS for HeLa-Cx43 cells and mechanical stress (MS) caused by 8 falling drops ( $10 \mathrm{~cm}$ high) of saline solution for HeLa-Panx1 cells. Masitinib (10 $\mu \mathrm{M}$ ) was applied during recordings after activation of HCs. Quantification of the Etd uptake rate was normalized according to basal uptake before stimulation (DCFS for HeLa (x43 and MS for HeLa Panx1) and after masitinib exposure ${ }^{* *} p<0.005$ and ${ }^{* * *} p<0.0005$ ANOVA Tukey test, n.s.). $\boldsymbol{E}$, Etd (50 $\left.\mu \mathrm{M}\right)$ uptake rate in WT MCs before and after treatment with $10 \mu \mathrm{m} \mathrm{A} \beta_{25-35}$ peptide normalized with respect to the basal uptake. Cells were also exposed to a divalent DCFS and then treated with $200 \mu \mathrm{m} \mathrm{La}{ }^{3+}$. A significant difference was tested by ANOVA and Tukey test $\left({ }^{* *} p<0.005 ; n=3\right)$. In $\boldsymbol{D}$ and $\boldsymbol{E}$, each value represents the average \pm SEM of at least 40 cells $(n=3)$.

activity (Schalper et al., 2008). Furthermore, quantification of Etd uptake rate after treatment with 10 or $20 \mu \mathrm{M} \mathrm{A} \beta_{25-35}$ peptide showed no significant difference with respect to control conditions in WT MCs ( $1.0 \pm 0.1$ and $1.2 \pm 0.1$-fold, respectively, both $n=3$, n.s. with respect to control conditions, $p>0.05$ ), whereas treatment with a cation-divalent-free solution (DCFS) promoted Etd uptake $\left(1.8 \pm 0.2\right.$-fold, $\left.{ }^{* *} p<0.005 ; n=3\right)$, which in turn was inhibited by $\mathrm{La}^{3+}(0.8 \pm 0.1$-fold, n.s., $p>0.05 ; n=3$; Fig. $3 E)$, suggesting the presence of HCs formed by Cxs known to be expressed by MCs (Vliagoftis et al., 1999). Therefore, all dye uptake experiments in BMMCs were done with DAPI as the permeability probe.

Panx1 participates in $\mathrm{Ca}^{2+}$ signals induced by $\mathrm{A} \boldsymbol{\beta}_{25-35}$ peptide in MCs

Because $\mathrm{Ca}^{2+}$ influx is essential for MC degranulation (Parekh and Putney, 2005) and Panx1 HCs are permeable to $\mathrm{Ca}^{2+}$
(Vanden Abeele et al., 2006), we investigated whether Panx1 HCs are involved in $\mathrm{Ca}^{2+}$ signals induced by $\mathrm{A} \beta_{25-35}$ peptide (Fig. 4). Representative images of Fura 2-loaded WT MCs at $200 \mathrm{~s}$ under control conditions and after $400 \mathrm{~s}$ exposure to $10 \mu \mathrm{M} \mathrm{A} \beta_{25-35}$ peptide are shown in Figure $4, A$ and $B$, respectively. $\mathrm{A} \beta_{25-35}$ peptide induced a rapid and transient $\mathrm{Ca}^{2+}$ signal increase, followed by a plateau level of fluorescence ratio (340/380). This ratio was drastically reduced in MCs pretreated for $20 \mathrm{~min}$ with probenecid (1 mM), a Panx1 HC blocker, or in MCs from Panx $1^{-/-}$ mice. Under these two conditions, only the rapid and transient $\mathrm{Ca}^{2+}$ signal increase was evident, which then returned to the initial values (Fig. $4 C$ ). It is relevant to mention that $\mathrm{Ca}^{2+}$ signal before stimulation was slightly higher in WT MCs under control conditions than in WT MCs treated with probenecid or in Panx $1^{-/-}$MCs, suggesting the involvement of Panx1 HCs in the control of the basal intracellular free $\mathrm{Ca}^{2+}$ concentration. Accordingly, WT MCs bathed in DCFS showed lower basal $\mathrm{Ca}^{2+}$ 

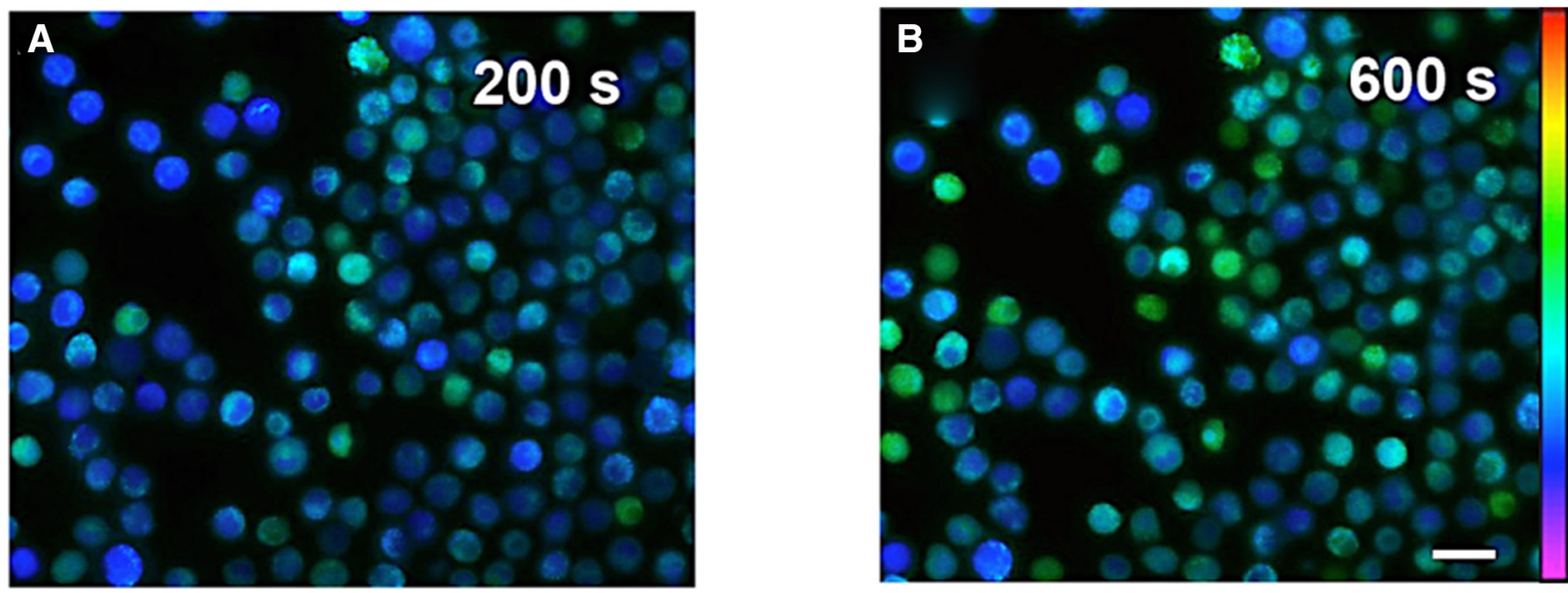

C

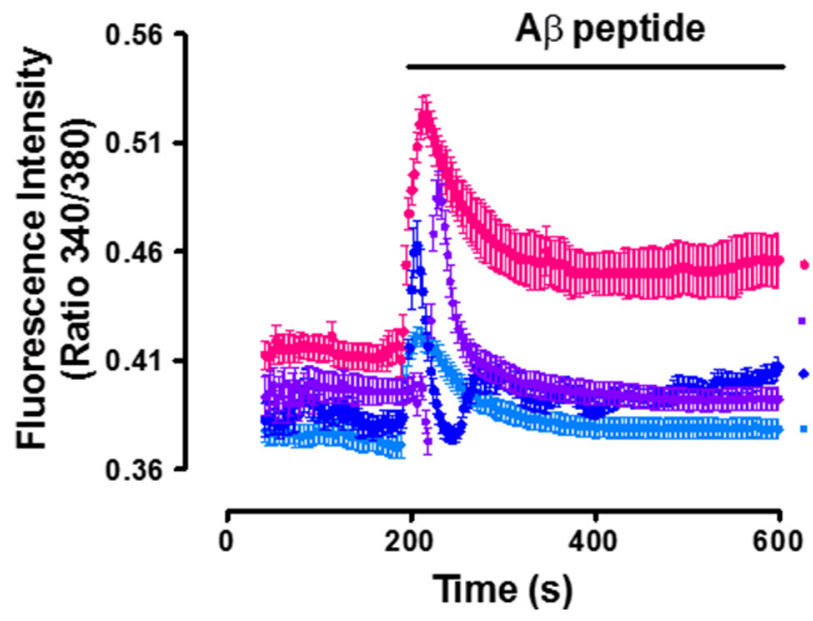

D

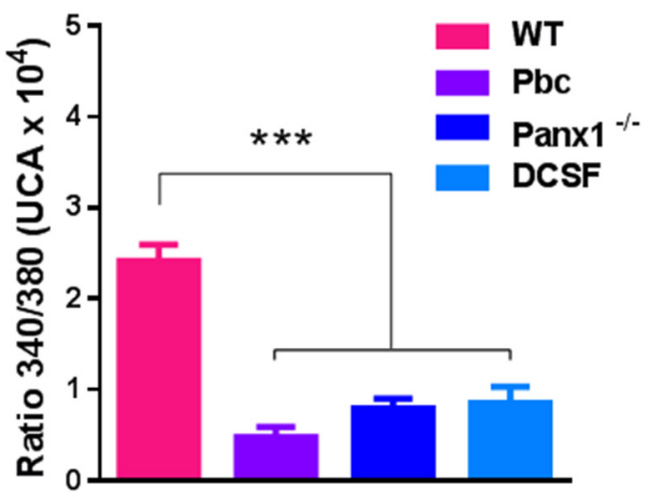

Figure 4. The basal intracellular $\mathrm{Ca}^{2+}$ signal and the sustained $\mathrm{A} \beta_{25-35}$ peptide-induced phase of the $\mathrm{Ca}^{2+}$ signal increase in $\mathrm{MCs}$ is Panx $1 \mathrm{HC}$ dependent. The $\mathrm{Ca}^{2+}$ signal was evaluated under basal conditions and after treatment with $10 \mu \mathrm{MA} \beta_{25-35}$ peptide in WT and Panx $1^{-1-} \mathrm{MCs}$ loaded with Fura-2. $\boldsymbol{A}, \boldsymbol{B}$, Representative images of $\mathrm{Ca}^{2+}$ signal in WT MCs during resting condition $(200 \mathrm{~s} ; \boldsymbol{A})$ and after treatment with $10 \mu \mathrm{M} \mathrm{A} \beta_{25-35}$ peptide (600 s; plateau or sustained phase; $\left.\boldsymbol{B}\right)$. Scale bar, $20 \mu \mathrm{m}$. C, Fura-2 fluorescence emission over time in Panx ${ }^{-1-}$ (blue) and WT MCs treated with $10 \mu \mathrm{M} \mathrm{A} \beta_{25-35}$ peptide (A $\beta$ peptide) under control conditions (pink), after 10 min pretreatment with $1 \mathrm{~mm}$ probenecid (Pbc, purple), or exposed to DCFS (light blue). Each point represents the average of 50 cells (mean \pm SEM; $n=5$ ). $\boldsymbol{D}$, Area under curve from ratio $340 / 380$ fluorescence signals. Values represent the mean \pm SEM $\left({ }^{* * *} p<0.0005\right.$, ANOVA Tukey's test; $n=5$ ).

signal and, after treatment with $\mathrm{A} \beta_{25-35}$ peptide, significantly lower $\mathrm{Ca}^{2+}$ signal (Fig. 4D), which is consistent with the possible participation of Panx1 HCs in both the rapid and transient increase and the plateau level that follows it.

\section{$\mathrm{A} \boldsymbol{\beta}_{25-35}$ peptide-induced degranulation of MCs requires functional Panx1 HCs}

To determine whether Panxl participates in the degranulation response induced by amyloid peptide, we compared the effect of $10 \mu \mathrm{M} \mathrm{A} \beta_{25-35}$ peptide on MCs from WT and Panx1 ${ }^{-1-}$ mice with two different approaches (Fig. 5). First, MCs were loaded with $\mathrm{TB}$, an alkaline blue dye retained in secretion granules (Shukla et al., 2006). Therefore, the loss of blue staining was considered to be a degranulation indicator. After $10 \mathrm{~min}$ of $10 \mu \mathrm{M}$ $\mathrm{A} \beta_{25-35}$ peptide treatment, MCs exhibited enhanced TB loss (Fig. $5 A$, top), which did not occur in Panx $1^{-1-}$ MCs (Fig. $5 A$, bottom). A representative time-lapse recording of TB staining intensity was plotted to show the $\mathrm{A} \beta_{25-35}$ peptide-induced loss of TB in WT but not in Panx1 ${ }^{-/-}$MCs (Fig. $5 B$ ). After treatment with 10 $\mu \mathrm{M} \mathrm{A} \beta_{25-35}$ peptide, the rate of blue intensity loss was enhanced
$2.2 \pm 0.2$-fold with respect to control conditions $\left({ }^{* * *} p<0.0005\right.$; $n=4)$. The inverted peptide did not significantly affect the rate of blue intensity loss ( $1.2 \pm 0.1$-fold, n.s., $p>0.05 ; n=4)$. Moreover, the rate of blue intensity loss induced by $\mathrm{A} \beta_{25-35}$ peptide was completely prevented by 20 min of pretreatment with $1 \mathrm{~mm}$ probenecid ( $1.1 \pm 0.1$-fold, n.s., $p>0.05 ; n=4)$. In addition, the Panx $1^{-1-}$ MCs did not show significant changes in rate of blue intensity loss after treatment with $10 \mu \mathrm{M} \mathrm{A} \beta_{25-35}$ peptide (1.2 \pm 0.2 -fold, n.s., $p>0.05 ; n=4$; Fig. $5 C$ ).

The second approach used to evaluate the degranulation of MCs was to measure the histamine released to the extracellular saline solution. After $20 \mathrm{~min}$ of treatment with $10 \mu \mathrm{M} \mathrm{A} \beta_{25-35}$, the histamine release of WT MCs was significantly increased (2.0 \pm 0.1 times, $\left.{ }^{* *} p<0.0005 ; n=3\right)$, whereas treatment with the inverted peptide had no effect $(0.9 \pm 0.1$-fold, n.s., $p>0.05 ; n=$ 3 ; Fig. $5 D$, black columns). Furthermore, the extracellular histamine levels were not affected after $20 \mathrm{~min}$ of treatment with $\mathrm{A} \beta_{25-35}$ or the inverted peptide in Panx1 ${ }^{-1-} \mathrm{MCs}$ (1.0 \pm 0.1 -fold and $1.2 \pm 0.1$-fold, respectively, n.s., $p>0.05 ; n=3$; Fig. $5 D$, white columns). 
A
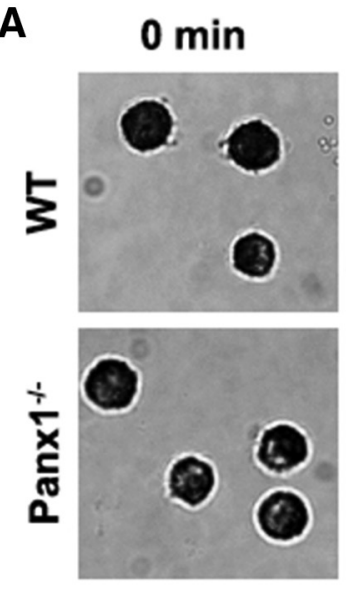

C

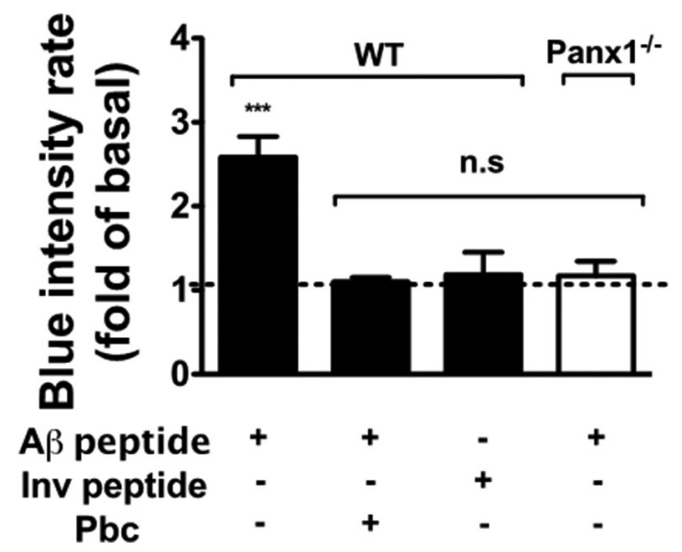

B

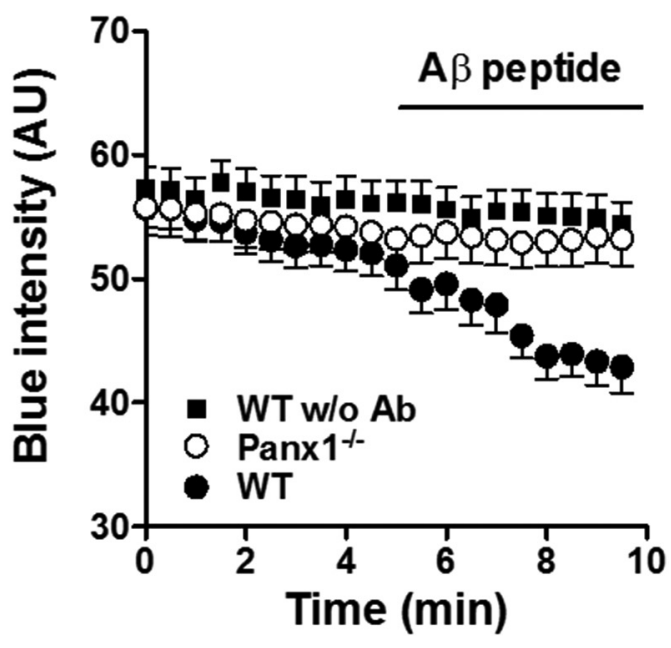

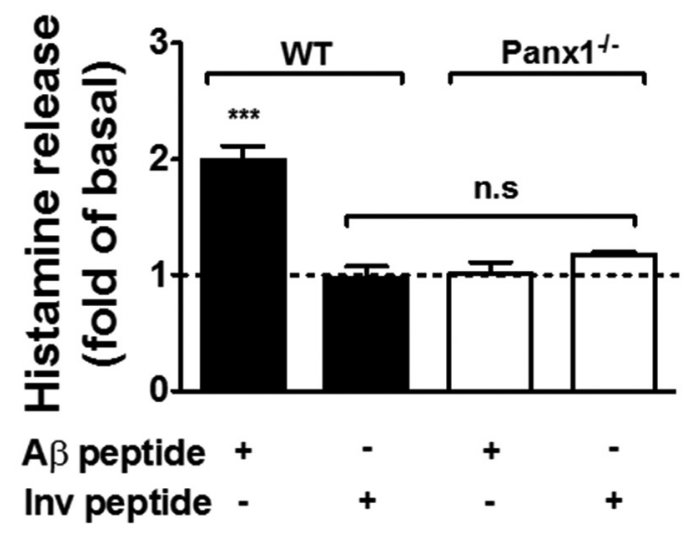

Figure 5. Panx $1 \mathrm{HCs}$ are essential for $A \beta_{35-42}$ peptide-induced MC degranulation. The degranulation response of WT and Panx 1 knock-out (Panx $1^{-/-}$) MCs induced by $10 \mu \mathrm{MA} \beta_{25-35}$ peptide was evaluated through the loss of TB intensity staining and histamine release. $A$, Representative images of TB-loaded WT (top) and Panx $1^{-1-}$ (bottom) MCs before and after 15 min treatment with $10 \mu \mathrm{mA} \beta_{25-35}$ peptide. Scale bar, $20 \mu \mathrm{m}$. B, Time-lapse measurements of blue intensity loss in WT (black circles) and Panx1 ${ }^{-1-}$ (white circles) MCs before and after treatment with $A \beta_{25-35}$ peptide. TB intensity loss under basal conditions in WT MCs is plotted as black squares. C, Quantification of normalized rate of blue intensity loss induced by A $\beta_{25-35}$ peptide with respect to control conditions in WT (black) and Panx $1^{-1-}$ MCs (white). D, Extracellular histamine levels under control conditions and after 20 min of treatment with $A \beta_{25-35}$ or A $\beta_{35-25}$ inverted (Inv) peptides in WT (black) and Panx $1^{-/-}$(white) MCs ${ }^{* *} p<0.005$ and ${ }^{* * *} p<0.0005$ ANOVA Tukey test, n.S., values represent the mean \pm SEM; $n=4$ for TB assays and $n=3$ for histamine release).

$\mathrm{A} \boldsymbol{\beta}_{25-35}$ peptide induces Cx43 and Panx1 HC opening in brain MCs

We also studied whether $\mathrm{A} \beta_{25-35}$ peptide affects the $\mathrm{HC}$ activity of MCs by assessing Etd uptake in acute brain slices. Coronal brain slices were exposed to $10 \mu \mathrm{M} \mathrm{A} \beta_{25-35}$ peptide and then incubated for $10 \mathrm{~min}$ with $4 \mu \mathrm{m}$ Etd, washed with ASCF, fixed, and finally processed for immunodetection of CD117 to evaluate dye uptake specifically in MCs (Fig. 6A). We first studied the time course of the $A \beta_{25-35}$ peptide-induced dye uptake of MCs. All values of Etd uptake were referred to the value measured in brain slices under their time-respective control conditions, referred to as $100 \%$ in every case. After $\mathrm{A} \beta_{25-35}$ peptide addition, brain slices were incubated for different time spans: $0.25,0.5,1$, and $2 \mathrm{~h}$. An increase in Etd uptake was already detected at $0.25 \mathrm{~h}$ of treatment $\left(162.9 \pm 12.4 \%,{ }^{*} p<0.05 ; n=3\right)$, increased further at $0.5 \mathrm{~h}$ $\left(206.4 \pm 11.3 \%,{ }^{* *} p<0.0005 ; n=3\right)$, and remained at the same level from 0.5 to $2 \mathrm{~h}$ (Fig. $6 A$, right).

The responses induced by amyloid neurotoxic fragment $\mathrm{A} \beta_{25-35}$ were comparable to the ones induced by $\mathrm{A} \beta_{1-42}$ peptide, the predominant $\mathrm{A} \beta$ peptide found in neuritic plaques (Masters et al., 1985; Fig. $6 A$, right, gray columns). After a $1 \mathrm{~h}$ treatment with $\mathrm{A} \beta_{1-42}$ peptide, Etd uptake increased significantly (186.6 \pm $22.2 \%,{ }^{\star} p<0.05 ; n=3$ ) with respect to the control condition.

To evaluate the involvement of $\mathrm{Cx}$ and Panxl HCs in the $\mathrm{A} \beta_{25-35}$ peptide-induced Etd uptake, brain slices were pretreated for 20 min with different general and specific HC blockers or a mixture of them before applying the amyloid peptide. To avoid variations due to incomplete responses, we used $2 \mathrm{~h} \mathrm{~A} \beta_{25-35}$ peptide stimulation in all of the following experiments. In brain slices treated for $2 \mathrm{~h}$ with $\mathrm{A} \beta_{25-35}$ peptide, a significant increase in Etd uptake was evident $\left(208.5 \pm 10.2 \%,{ }^{* * *} p<0.0005 ; n=5\right)$. With respect to amyloid treatment, we found that both $\mathrm{Cx} 43\left[\mathrm{La}^{3+}\right.$ $\left(147.6 \pm 19.7 \%,{ }^{\star} p<0.05, n=3\right)$ and Gap26 $(138.7 \pm 16.9 \%$, $\left.{ }^{\star} p<0.05 ; n=3\right)$ ] and Panx1 [probenecid $\left(152.1 \pm 22.3 \%,{ }^{\star} p<\right.$ $0.05 ; n=3)$ and $\left.{ }^{10} \operatorname{Panx} 1\left(152.0 \pm 15.5 \%,{ }^{*} p<0.05 ; n=3\right)\right] \mathrm{HC}$ blockers induced similar partial inhibition of the $A \beta_{25-35}$ peptide-induced Etd uptake (Fig. 6B). However, the simultaneous inhibition of $\mathrm{Cx} 43$ and Panx1 HCs with $\mathrm{La}^{3+}$ and $\mathrm{Pbc}$ $\left(109.7 \pm 5.5 \%, n=3,{ }^{* *} p<0.0005\right)$, or Gap26 and ${ }^{10} \mathrm{Panx} 1$ mimetic peptide $\left(111.7 \pm 16.6 \%,{ }^{* * *} p<0.0005 ; n=3\right)$ completely prevented the $A \beta_{25-35}$ peptide-induced Etd uptake (Fig. $6 B)$. Interestingly, pretreatment with $10 \mu \mathrm{M}$ masitinib also pre- 

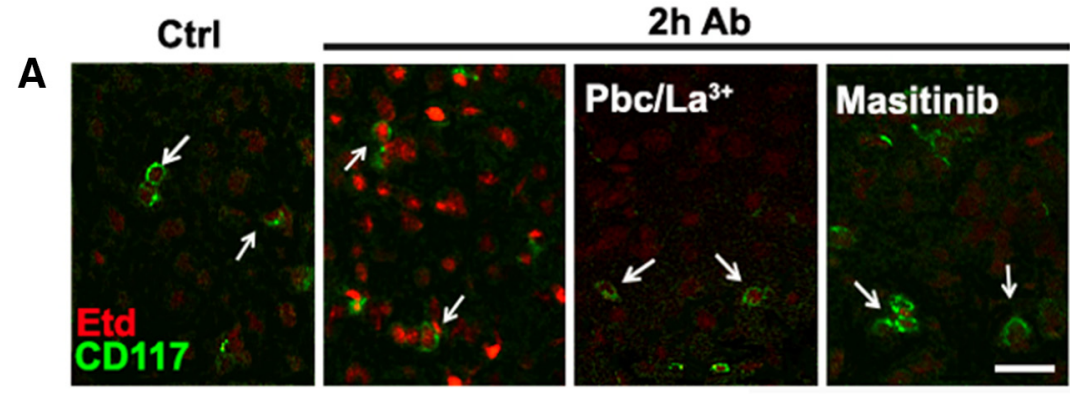

B

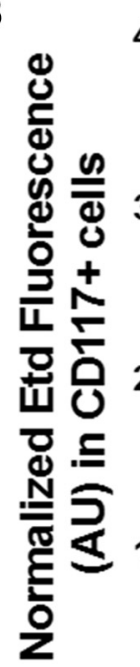

${ }^{400}$

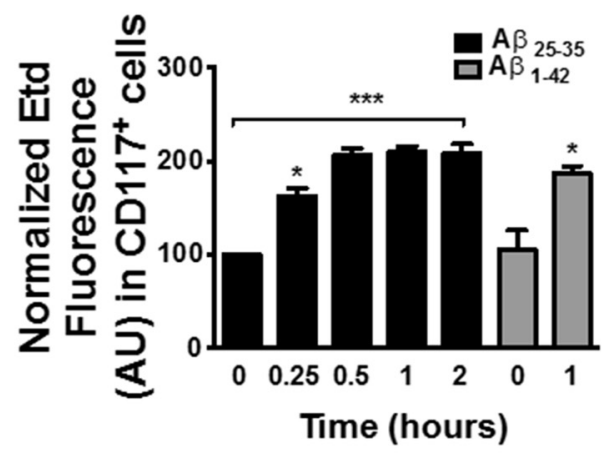


bated simultaneously with $\mathrm{La}^{3+}$ and probenecid, the values were indistinguishable from those measured under control conditions $(0.9 \pm 0.1$-fold, $n=3)$. A $\beta_{25-35}$ peptide also induced histamine release in Panx1 $1^{-1-}$ brain slices to a similar extent as that measured in WT brain slices (2.0 \pm 0.3 -fold, $n=3$; Fig. 7). $\mathrm{La}^{3+}$ completely prevented the histamine release induced by $\mathrm{A} \beta_{25-35}$ peptide $(0.7 \pm 0.2$-fold, $n=3)$, whereas probenecid pretreatment did not significantly affect it ( $1.9 \pm 0.3$-fold, $n=3)$. Accordingly, pretreatment with $\mathrm{La}^{3+}$ plus probenecid prevented the bioamine release to the same extent as $\mathrm{La}^{3+}$ alone $(0.9 \pm$ 0.2 -fold, $n=3$ ), suggesting that, in acute brain slices, the $\mathrm{A} \beta_{25-35}$ peptide-induced histamine release is mainly associated with an increase in $\mathrm{Cx} 43 \mathrm{HC}$ activity.

\section{Number of MCs is highly increased in brain slices of APPswe/PS1dE9 mice}

Because postmortem samples of brain from $\mathrm{AD}$ patients show a close association between MCs with amyloid deposits (Kvetnoi et al., 2003; Maslinska et al., 2007), we decided to study the HC activity of brain MCs in a murine model of $\mathrm{AD}$, APPswe/PS1dE9 mice. These mice exhibit some characteristics of $\mathrm{AD}$, including the development of amyloid plaques that become detectable during the fourth month after birth and accumulate with age (Jankowsky et al., 2005; GarciaAlloza et al., 2006; Mei et al., 2010).

First, we examined the distribution and abundance of MCs in brain slices of 3- to 12-month-old APPswe/PS1dE9 mice. Representative images of coronal brain sections of 6-month-old WT and APPswe/PS1dE9 mice are shown in Figure $8, A$ and $B$, respectively. In WT mice, MCs (CD117-positive cells) were found mainly in the cortex and thalamus, whereas in APPswe/PS1dE9 mice, they were more abundant in the cortex and hippocampus. Notably, in brain slices of APPswe/PS1dE9 mice, MCs were located close to amyloid plaques (Fig. 8D).

Quantification of MCs in serial brain sections at different ages is presented in Figure $8 C$. In 3-month-old APPswe/PS1dE9 mice, a higher number of MCs was detected $\left(19.3 \pm 1.7 \times 10^{-3}\right.$ cells $/ \mathrm{mm}^{2}$ vs WT, see below), but amyloid plaques were not yet detectable. In 4-month-old APPswe/ PS1dE9 mice with the onset of amyloid deposition, the number of MCs was $18.6 \pm$ $0.7 \times 10^{-3}$ cells $/ \mathrm{mm}^{2}(n=3)$. In 6- and 12-month-old APPswe/PS1dE9 mice, the MC count increased to $24.9 \pm 3.2 \times 10^{-3}$ cells $/ \mathrm{mm}^{2}$ and $24.8 \pm 1.9 \times 10^{-3}$ cells/ $\mathrm{mm}^{2}$, respectively $(n=3)$. Finally, in 16month-old mice, the number of MCs was slightly lower than that studied at earlier ages $\left(19.2 \pm 3.5 \times 10^{-3}\right.$ cells $\left./ \mathrm{mm}^{2} ; n=3\right)$, but still significantly higher than that in WT mice. Because, in WT mice, the number of MCs was similar at all ages evaluated, we projected the number of MCs from the quantification made at $3\left(11.4 \pm 1.0 \times 10^{-3}\right.$ cells $\left./ \mathrm{mm}^{2} ; n=3\right), 6(10.6 \pm$ $1.8 \times 10^{-3}$ cells $\left./ \mathrm{mm}^{2} ; n=3\right)$, and $12(9.4 \pm 1.3 \times$ $10^{-3}$ cells $/ \mathrm{mm}^{2} ; n=3$ ) months of age.

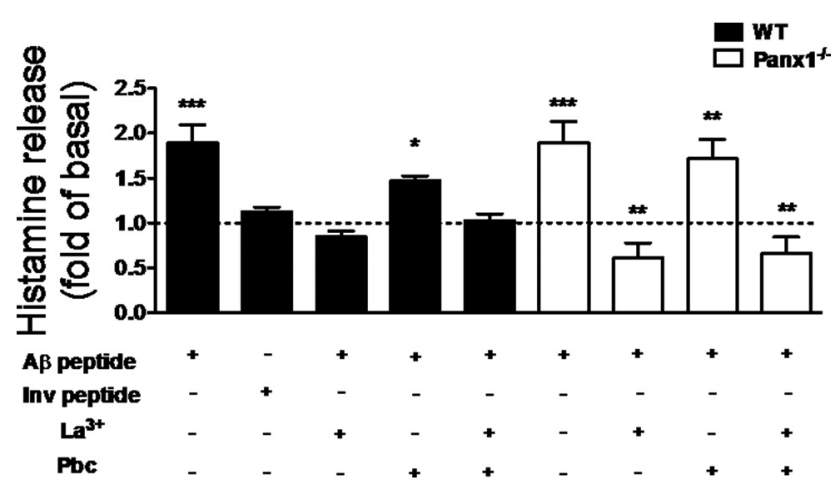

Figure 7. The $\mathrm{A} \beta_{25-35}$ peptide-induced histamine release from brain slices is $\mathrm{HC}$ dependent Histamine levels were evaluated in samples of the saline solution that bathed brain slices of WT (black) or Panx 1 knock-out (Panx $1^{-1-}$, white) mice under control conditions pretreated or not for 20 min with $200 \mu \mathrm{m} \mathrm{La}{ }^{3+}$, a Cx HC blocker, or with 1 mm probenecid (Pbc), a Panx HC blocker, and then treated for $2 \mathrm{~h}$ with $\mathrm{A} \beta_{25-35}$ or $\mathrm{A} \beta_{35-25}$ inverted (Inv) peptide ( ${ }^{*} p<0.05$, ${ }^{* *} p<0.005$, and ${ }^{* * *} p<0.0005$, ANOVA Tukey's test, n.S., values are mean \pm SEM; $n=5$ ).
A

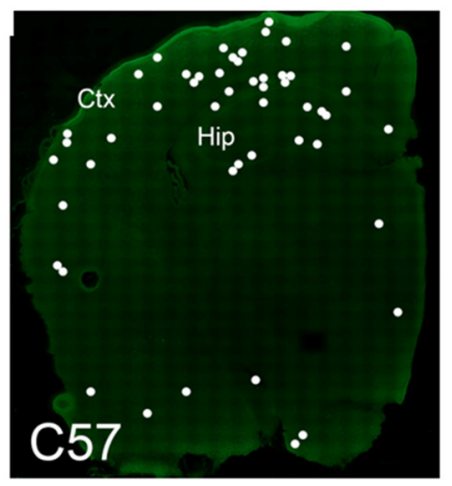

$\mathbf{B}$

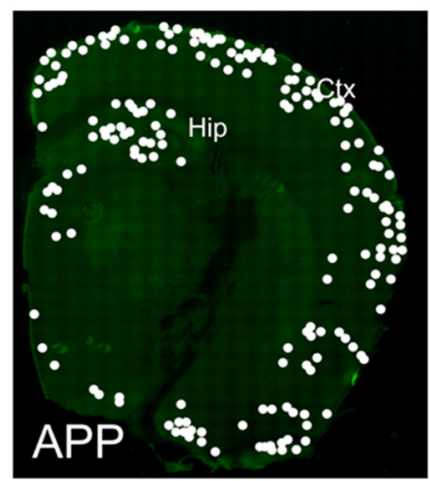

C
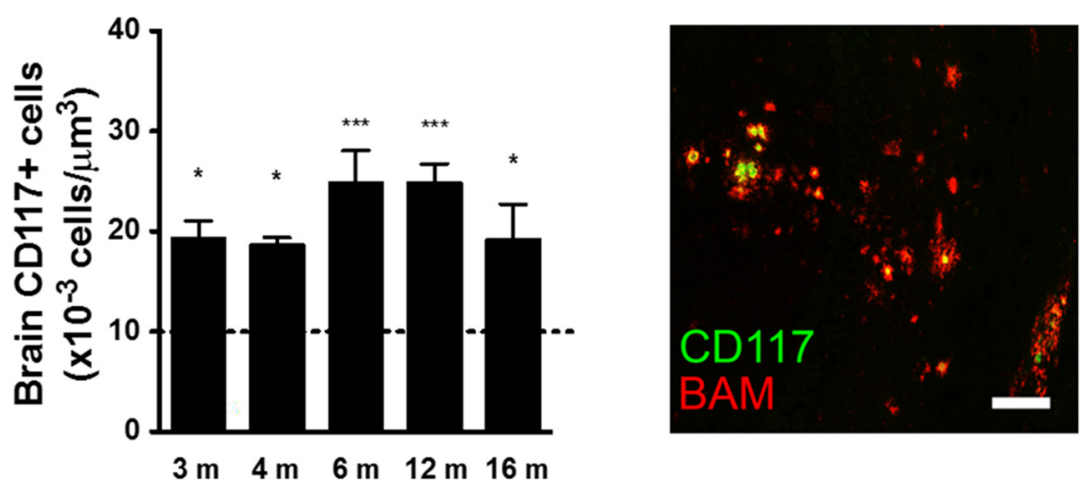

Figure 8. During adulthood, the number of MCs present in coronal brain sections is higher in APPswe/PS1dE9 than in WT mice. Coronal brain sections of 6-month-old WT (C57, left hemisphere; $\boldsymbol{A}$ ) and APPswe/PS1dE9 (APP, right hemisphere; $\boldsymbol{B}$ ) mice immunostained for the molecular MC marker CD117. White dots indicate positive staining. Cortex (Ctx) and hippocampus (Hip) are indicated. C, MC quantification per cubic millimeter in the cortex and hippocampus of APPswe/PS1dE9 mice at different ages as indicated. Dotted line indicates a projection of the number of MCs quantified for 3-, 6-, and 12-month-old WT mice. Each number represents the mean \pm SEM $\left({ }^{* * *} p<0.05\right.$ and ${ }^{*} p<0.05$, ANOVA Tukey's test, n.s.; $n=3$ ). $\boldsymbol{D}$, Representative image of a brain section from an 8-month-old APPswe/PS1dE9 mouse showing immunostained MCs (anti-CD117 antibody, green) and amyloid plaques (anti-A $\beta$ antibody called BAM, red). Scale bars: $\boldsymbol{A}, \boldsymbol{B}, 100 \mu \mathrm{m} ; \boldsymbol{D}, 50 \mu \mathrm{m}$.

\section{Brain MCs of APPswe/PS1dE9 mice show high Panx1 and Cx43 HC activity}

Because the opening of HCs was found to be essential for the degranulation response of MCs, we next examined MC HC activity in brain slices of APPswe/PS1dE9 mice as an indicator of the activation state 
A
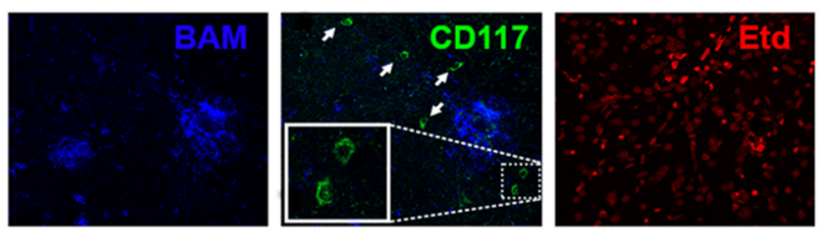

B

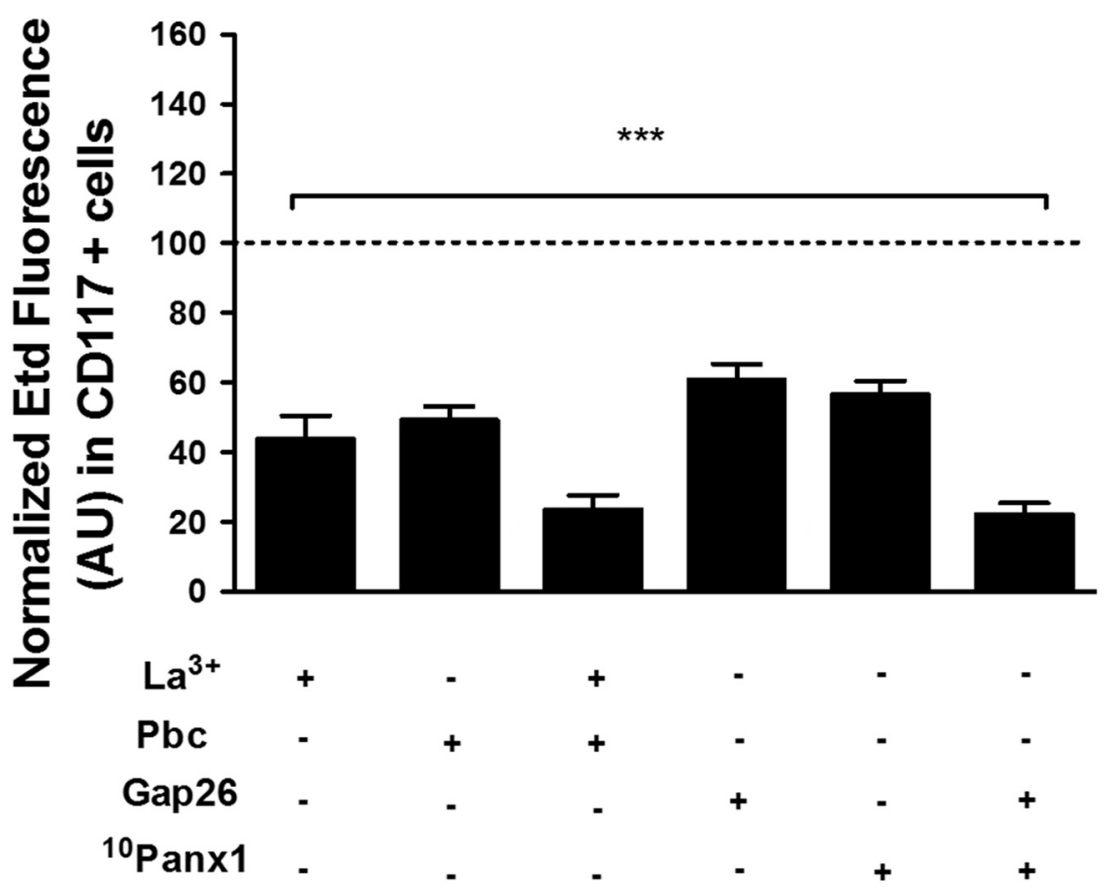

Figure 9. Panx1 and $\mathrm{C} \times 43 \mathrm{HCs}$ are activated in MCs present in brain slices of APPswe/PS1dE9 mice. $\boldsymbol{A}$, Representative image of Etd uptake (red) in a coronal brain slice of an 8-month-old APPswe/PS1dE9 mouse doubly immunostained for amyloid plaques detected with an antibody to APP called BAM (blue) and MCs detected by their CD117 reactivity (green). Arrows denote CD117positive cells; 2 cells within the dotted square are $3 \times$ magnified in the left inset. Scale bar, $50 \mu \mathrm{m}$. B, Quantification of normalized Etd fluorescence intensity with respect to basal conditions in CD117-positive cells of APPswe/PS1dE9 mice before (basal condition indicated with the dotted line) and after treatment with Cx (200 $\mu \mathrm{m} \mathrm{La}{ }^{3+}$ and $200 \mu \mathrm{m}$ Gap26 mimetic peptide) or Panx [1 mM probenecid (Pbc) and $200 \mu \mathrm{M}{ }^{10} \mathrm{Panx} 1$ mimetic peptide] HC blockers ( ${ }^{* * *} p<0.0005$, ANOVA Tukey's test). Values are mean \pm $\operatorname{SEM}\left(n=3\right.$ for $\mathrm{La}^{3+}, \mathrm{Pbc}$, and mixture; $n=4$ for peptides).

of MCs. Dye uptake was evaluated in coronal brain slices of APPswe/ PS1dE9 mice before and after treatment with Cx43 and Panx1 HC blockers in CD117-positive cells. Representative confocal images of a brain slice obtained from an 8-month-old APPswe/PS1dE9 mouse are shown in Figure 9A. After 10 min of Etd exposure, CD117positive cells showed increased dye uptake compared with those of WT mice. This HC activity was reduced by either $\mathrm{Cx} 43 \mathrm{HC}$ blockers [reduced to $43.8 \pm 6.6 \%$ by $\mathrm{La}^{3+}(n=4)$ and to $60.9 \pm 4.4 \%$ by Gap26 $(n=3)$ ] or Panx1 HC blockers [reduced to $49.2 \pm 3.9 \%$ by probenecid $(n=4)$ and $56.6 \pm 3.8 \%$ by $\left.{ }^{10} \mathrm{Panx} 1(n=3)\right]$. Further reduction in Etd uptake was obtained by simultaneous treatment with $\mathrm{Cx} 43$ and Panx1 blockers [reduced to $26.5 \pm 2.4 \%$ by probenecid plus $\mathrm{La}^{3+}(n=4)$, and $26.3 \pm 2.7 \%$ by Gap26 plus ${ }^{10} \mathrm{Panx} 1$ $(n=3)$ ] (Fig. 9B).

\section{Discussion}

In the present work, $\mathrm{A} \beta_{25-35}$ peptide was shown to induce rapid degranulation of cultured MCs via a Panx1 HC-dependent mechanism. In brain MCs, $\mathrm{A} \beta_{25-35}$ peptide also induced $\mathrm{HC}$ activity that was both Panx1 and Cx43 dependent. In this context, a $\mathrm{Cx} 43$ and Panx1 HC-dependent mechanism also mediated the $\mathrm{A} \beta_{25-35}$ peptide-induced degranulation of brain MCs. Finally, in an ADtransgenic animal model, APPswe/PS1dE9 mice, the number of

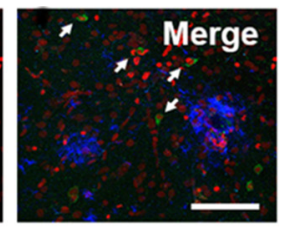

brain MCs was increased in regions that exhibited amyloid plaques: the hippocampus and cortex. Such an increase was already detectable in young mice before the appearance of amyloid plaques. In this model, when the amyloid plaques are present, high Cx43 and Panx1 HC activity in brain MCs was found, suggesting a persistent activation of MCs.

It has been demonstrated that a single application of $\mathrm{A} \beta_{25-35}$ peptide induces membrane permeabilization via $\mathrm{HCs}$ first in microglia, followed by astrocytes and then neurons (Orellana et al., 2011). In these brain cells, increased HC activity occurred after several hours of $\mathrm{A} \beta_{25-35}$ peptide application (Orellana et al., 2011). In agreement with the report by Niederhoffer et al. (2009), we now show that MCs respond to amyloid peptide earlier than any of the cell types mentioned above. The increase in total membrane current and the increase in cell membrane permeability occurred after a few minutes $(<5 \mathrm{~min})$ of MC exposure to the $\mathrm{A} \beta_{25-35}$ peptide. Consistent with this, degranulation of MCs evaluated by TB loss occurred after a similar time course to the increase in membrane current and in permeability changes, whereas the histamine release was already evident at 20 min after stimulation with $\mathrm{A} \beta_{25-35}$ peptide. Moreover, the increase in Etd uptake in brain MCs was maximal after $30 \mathrm{~min}$ of treatment with $\mathrm{A} \beta_{25-35}$ peptide. Because we used soluble peptide, it is likely that this form is sufficient to activate MCs both in vitro and in vivo, but this possibility needs further confirmation. In vivo, this might be relevant to our understanding about the onset of $\mathrm{AD}$ because the amyloid plaques are likely to be formed after a critical concentration of amyloid protein is reached.

So far, MCs have been shown to express Cx32 and Cx43 (Vliagoftis et al., 1999) and to form heterocellular gap junction channels with fibroblasts (Moyer et al., 2004; Au et al., 2007). Here, we have demonstrated that BMMC precursors also express Panx1, but not Panx2 or Panx3, suggesting that they form homomeric Panx1-HCs. This notion is consistent with unitary current events corresponding to conductance values close to the ones recorded by others for Panx1 HCs expressed in different cell types (Bao et al., 2004; Locovei et al., 2006). In addition, these currents were inhibited by the mimetic peptide ${ }^{10} \mathrm{Panx} 1$, a selective blocker of Panx1 HCs (Pelegrin and Surprenant, 2006; Wang et al., 2007). Moreover, MCs presented DAPI (MW: 279, net charge: +2) uptake induced by amyloid peptide, which was prevented by Panx1 HC blockers (carbenoxolone, probenecid, and ${ }^{10} \mathrm{Panx} 1$ peptide) and totally absent in MCs from Panx $1^{-1-}$ mice, supporting the notion that DAPI uptake was mediated by Panx1 HCs. Despite the fact that MCs did not show Etd (MW: 394.3, net charge +1 ) uptake induced by $\mathrm{A} \beta_{25-35}$ peptide, DCFS induced Etd uptake, indicating the presence of Cx HCs that were not activated by $\mathrm{A} \beta_{25-35}$ peptide. The lack of Etd permeability of Panx1 HCs induced by amyloid peptide in BMMCs is likely the 
result of molecular shape and/or size limitation (impermeable to cationic molecules with axial diameter larger than that of DAPI) rather than charge selectivity because DAPI is +2 and Etd is only +1 . In contrast, Panx1 HCs activated by ATP have been found permeable to Etd in several other cell types (Pelegrin and Surprenant, 2006; Schalper et al., 2008), suggesting that receptor type or transduction pathway activated by a ligand critically affects the permeability features of Panx1 HCs. In contrast to the BMMCs, we found Etd uptake via Panx1 HCs in brain MCs. This observation is mainly based on the effect of the Panx1 HC blockers probenecid and ${ }^{10} \mathrm{Panx} 1$. This apparent contradiction might be explained by cell type differences because BMMCs are not fully differentiated MCs and lack the tissue factors essentials for their maturation, whereas brain MCs were evaluated in a brain slice in the presence of a mature and complete cellular microenvironment.

Several membrane pathways have been proposed to mediate the $\mathrm{Ca}^{2+}$ influx required for MC degranulation (Ma and Beaven, 2011). For the degranulation response induced by the amyloid peptide, several steps have been identified and include recognition through the membrane protein complex CD47, activation of $\beta_{1}$ integrin subunit, and $\mathrm{G}_{\mathrm{i}}$ protein leading to $\mathrm{Ca}^{2+}$ influx, which is key for amyloid peptide-induced MC degranulation (Niederhoffer et al., 2009; Sick et al., 2009). Here, we have demonstrated that inhibition of Panx1 HCs or their lack of expression drastically reduced the basal $\mathrm{Ca}^{2+}$ signal and completely abrogated the persistent $\mathrm{Ca}^{2+}$ signal that follows the rapid and transient $\mathrm{Ca}^{2+}$ signal elicited by $\mathrm{A} \beta_{25-35}$ peptide. Therefore, Panx1 HCs appear to play a critical role in controlling the $\mathrm{Ca}^{2+}$ involved in $\mathrm{MC}$ degranulation induced by $\mathrm{A} \beta_{25-35}$ peptide. In agreement with this interpretation, the TB loss and histamine release were completely abolished by Panx1 HC blockers and by the lack of Panx1 expression.

Microglial cells, also resident immune cells of the brain, have been proposed to play a relevant role in the onset and progression of neuroinflammation in AD (Solito and Sastre, 2012; FigueraLosada et al., 2014). Activated microglia form clusters around amyloid deposits in humans (Wisniewski et al., 1989) and animal models (Frautschy et al., 1998; Radde et al., 2006) and have been proposed to play a key role in $\mathrm{AD}$ progression. In this context, in vitro studies have demonstrated that low concentrations of the active fragment of the amyloid peptide $\left(\mathrm{A} \beta_{25-35}\right)$ promote microglia activation, leading to astrocyte and neuron $\mathrm{HC}$ opening, which triggers neuronal death (Orellana et al., 2011). Moreover, our finding that MCs respond to the soluble $\mathrm{A} \beta_{25-35}$ peptide further supports that they are even earlier sensor, because they can detect a toxic form of $\mathrm{A} \beta$ peptide in less than a few minutes. Because the mouse model used in the present work exhibits only some characteristics of AD (Jankowsky et al., 2005; Garcia-Alloza et al., 2006; Mei et al., 2010), it remains to be determined whether MCs behave in a similar way in a more complete model of $\mathrm{AD}$ that includes the formation of neuronal tangles (Oddo et al., 2003a; 2003b).

As in $\mathrm{AD}$ patients, in whom MCs colocalize with amyloid deposits in several tissues (Kvetnoi et al., 2003; Maslinska et al., 2007), in APPswe/PS1dE9 mice, we found MCs intimately associated with amyloid plaque deposits. Because serum amyloid A induces chemotaxis of human MCs in vitro (Olsson et al., 1999) and rat MCs chymotrypsin-like protease generates $\beta$ amyloid protein in vitro (Nelson et al., 1993), we propose that MCs migrate from meninges to the cerebral parenchyma during early amyloid protein deposit accumulation, contributing to plaque formation and inflammation dependent on Panx1 and Cx43 HCs. The increased numbers of MCs in brains of APPswe/
PS1dE9 animals could be due an increased homing to the amyloid plaque deposits and/or proliferation of MCs around this lesion, but this needs further investigation.

Because masitinib, which is known to inhibit CD117 tyrosine kinase (Dubreuil et al., 2009), prevented the HC activation induced by $\mathrm{A} \beta_{25-35}$ peptide, not only in brain MCs but also in the rest of the parenchymal brain cells, and masitinib did not affect Etd uptake in HeLa-Cx43 nor HeLa-Panx1 cells, our data suggest that MC activation occurs upstream and that MCs are one of the first cells to recognize and respond to amyloid peptide.

Relevant to the possible role of MCs and HCs in the onset of $\mathrm{AD}$, we found that: (1) HCs expressed in brain MCs were activated by $\mathrm{A} \beta_{25-35}$ and $\mathrm{A} \beta_{1-42}$ peptides; (2) the histamine release was drastically increased by $\mathrm{A} \beta_{25-35}$ peptide via an $\mathrm{HC}$ dependent mechanism, and (3) brain MCs of APPswe/PS1dE9 mice showed high HC activity under basal conditions, suggesting that MCs were activated by the endogenously generated amyloid protein expressed by the transgenic mice. Therefore, MCs of APPswe/PS1dE9 mice likely release proinflammatory molecules chronically.

In conclusion, our findings indicate that MCs are highly sensitive to amyloid peptides and that their degranulation response leading to extracellular release of diverse proinflammatory molecules could trigger the onset of the pathology and might also promote the progression of AD. Therefore, Cx43 and Panx1 HCs expressed by MCs might serve as a molecular target with which to develop alternative therapeutic treatments that could delay the onset and progression of AD.

\section{References}

Anselmi F, Hernandez VH, Crispino G, Seydel A, Ortolano S, Roper SD, Kessaris N, Richardson W, Rickheit G, Filippov MA, Monyer H, Mammano F (2008) ATP release through connexin hemichannels and gap junction transfer of second messengers propagate $\mathrm{Ca} 2+$ signals across the inner ear. Proc Natl Acad Sci U S A 105:18770-18775. CrossRef Medline

Au SR, Au K, Saggers GC, Karne N, Ehrlich HP (2007) Rat mast cells communicate with fibroblasts via gap junction intercellular communications. J Cell Biochem 100:1170-1177. Medline

Bao L, Locovei S, Dahl G (2004) Pannexin membrane channels are mechanosensitive conduits for ATP. FEBS Lett 572:65-68. Medline

Bargiotas P, Krenz A, Hormuzdi SG, Ridder DA, Herb A, Barakat W, Penuela S, von Engelhardt J, Monyer H, Schwaninger M (2011) Pannexins in ischemia-induced neurodegeneration. Proc Natl Acad Sci U S A 108: 20772-20777. CrossRef Medline

Bruzzone R, Hormuzdi SG, Barbe MT, Herb A, Monyer H (2003) Pannexins, a family of gap junction proteins expressed in brain. Proc Natl Acad Sci U S A 100:13644-13649. CrossRef Medline

Cea LA, Cisterna BA, Puebla C, Frank M, Figueroa XF, Cardozo C, Willecke K, Latorre R, Sáez JC (2013) De novo expression of connexin hemichannels in denervated fast skeletal muscles leads to atropgy. Proc Natl Acad Sci U S A 110:16229-16234. Medline

Dubreuil P, Letard S, Ciufolini M, Gros L, Humbert M, Castéran N, Borge L, Hajem B, Lermet A, Sippl W, Voisset E, Arock M, Auclair C, Leventhal PS, Mansfield CD, Moussy A, Hermine O (2009) Masitinib (AB1010), a potent and selective tyrosine kinase inhibitor targeting KIT. PLoS One 4:e7258. CrossRef Medline

Fiala M, Chattopadhay M, La Cava A, Tse E, Liu G, Lourenco E, Eskin A, Liu PT, Magpantay L, Tse S, Mahanian M, Weitzman R, Tong J, Nguyen C, Cho T, Koo P, Sayre J, Martinez-Maza O, Rosenthal MJ, Wiedau-Pazos M (2010) IL-17A is increased in the serum and in spinal cord CD8 and mast cells of ALS patients. J Neuroinflammation 7:76. Medline

Figuera-Losada M, Rojas C, Slusher BS (2014) Inhibition of microglia activation as a phenotypic assay in early drug discovery. J Biomol Screen 19:17-31. CrossRef Medline

Fiori MC, Figueroa V, Zoghbi ME, Saéz JC, Reuss L, Altenberg GA (2012) Permeation of calcium through purified connexin 26 hemichannels. J Biol Chem 287:40826-40834. CrossRef Medline

Frautschy SA, Yang F, Irrizarry M, Hyman B, Saido TC, Hsiao K, Cole GM 
(1998) Microglial response to amyloid plaques in APPsw transgenic mice. Am J Pathol 152:307-317. Medline

Garcia-Alloza M, Robbins EM, Zhang-Nunes SX, Purcell SM, Betensky RA, Raju S, Prada C, Greenberg SM, Bacskai BJ, Frosch MP (2006) Characterization of amyloid deposition in the APPswe/PS1dE9 mouse model of Alzheimer disease. Neurobiol Dis 24:516-524. CrossRef Medline

Graves MC, Fiala M, Dinglasan LA, Liu NQ, Sayre J, Chiappelli F, van Kooten C, Vinters HV (2004) Inflammation in amyotrophic lateral sclerosis spinal cord and brain is mediated by activated macrophages, mast cells and T cells. Amyotroph Lateral Scler Other Motor Neuron Disord 5:213-219. CrossRef Medline

Ishikawa M, Iwamoto T, Nakamura T, Doyle A, Fukumoto S, Yamada Y (2011) Pannexin 3 functions as an ER $\mathrm{Ca}(2+)$ channel, hemichannel, and gap junction to promote osteoblast differentiation. J Cell Biol 193: 1257-1274. CrossRef Medline

Jankowsky JL, Slunt HH, Ratovitski T, Jenkins NA, Copeland NG, Borchelt DR (2001) Co-expression of multiple transgenes in mouse CNS: a comparison of strategies. Biomol Eng 17:157-165. CrossRef Medline

Jankowsky JL, Melnikova T, Fadale DJ, Xu GM, Slunt HH, Gonzales V, Younkin LH, Younkin SG, Borchelt DR, Savonenko AV (2005) Environmental enrichment mitigates cognitive deficits in a mouse model of Alzheimer's disease. J Neurosci 25:5217-5224. Medline

Jensen BM, Swindle EJ, Iwaki S, Gilfillan AM (2006) Generation, isolation, and maintenance of rodent mast cells and mast cell lines. Curr Protoc Immunol Chapter 3:Unit 3.23. CrossRef

Jordan JH, Walchshofer S, Jurecka W, Mosberger I, Sperr WR, Wolff K, Chott A, Bühring HJ, Lechner K, Horny HP, Valent P (2001) Immunohistochemical properties of bone marrow mast cells in systemic mastocytosis: evidence for expression of CD2, CD117/Kit, and bcl-x(L). Hum Pathol 32:545-552. CrossRef Medline

Khalil M, Ronda J, Weintraub M, Jain K, Silver R, Silverman AJ (2007) Brain mast cell relationship to neurovasculature during development. Brain Res 1171:18-29. Medline

Koulakoff A, Mei X, Orellana JA, Sáez JC, Giaume C (2012) Glial connexin expression and function in the context of Alzheimer's disease. Biochim Biophys Acta 1818:2048-2057. Medline

Kvetnoi IM, Kvetnaia TV, Riadnova IIu, Fursov BB, Ernandes-Jago H, Blesa JR (2003) Expression of beta-amyloid and tau-protein in mastocytes in Alzheimer disease [article in Russian]. Arkh Patol 65:36-39. Medline

Locovei S, Bao L, Dahl G (2006) Pannexin 1 in erythrocytes: function without a gap. Proc Natl Acad Sci U S A 103:7655-7659. CrossRef Medline

Lozada A, Maegele M, Stark H, Neugebauer EM, Panula P (2005) Traumatic brain injury results in mast cell increase and changes in regulation of central histamine receptors. Neuropathol Appl Neurobiol 31:150-162. Medline

Ma HT, Beaven MA (2011) Regulators of $\mathrm{Ca}(2+)$ signaling in mast cells: potential targets for treatment of mast cell-related diseases? Adv Exp Med Biol 716:62-90. Medline

Makarenkova HP, Shestopalov VI (2014) The role of pannexin hemichannels in inflammation and regeneration. Front Physiol 5:63. Medline

Maslinska D, Laure-Kamionowska M, Maslinski KT, Gujski M, Maslinski S (2007) Distribution of tryptase-containing mast cells and metallothionein reactive astrocytes in human brains with amyloid deposits. Inflamm Res 56:S17-S18. Medline

Masters CL, Simms G, Weinman NA, Multhaup G, McDonald BL, Beyreuther K (1985) Amyloid plaque core protein in Alzheimer disease and Down syndrome. Proc Natl Acad Sci U S A 82:4245-4249. Medline

Mei X, Ezan P, Giaume C, Koulakoff A (2010) Astroglial connexin immunoreactivity is specifically altered at beta-amyloid plaques in betaamyloid precursor protein/presenilin1 mice. Neuroscience 171:92-105. Medline

Metcalfe DD, Baram D, Mekori YA (1997) Mast cells. Physiol Rev 77:10331079. Medline

Moyer KE, Saggers GC, Ehrlich HP (2004) Mast cells promote fibroblast populated collagen lattice contraction through gap junction intercellular communication. Wound Repair Regen 12:269-275. Medline

Nelson RB, Siman R, Iqbal MA, Potter H (1993) Identification of a chymotrypsin-like mast cell protease in rat brain capable of generating the $\mathrm{N}$-terminus of the Alzheimer amyloid beta-protein. J Neurochem 61: 567-577. Medline

Niederhoffer N, Levy R, Sick E, Andre P, Coupin G, Lombard Y, Gies JP (2009) Amyloid beta peptides trigger CD47-dependent mast cell secre- tory and phagocytic responses. Int J Immunopathol Pharmacol 22:473483. Medline

Oddo S, Caccamo A, Kitazawa M, Tseng BP, LaFerla FM (2003a) Amyloid deposition tangle formation in a triple transgenic model of Alzheimer's disease. Neurobiol Aging 24:1063-1070. Medline

Oddo S, Caccamo A, Shepherd JD, Murphy MP, Golde TE, Kayed R, Metherate R, Mattson MP, Akbari Y, LaFerla FM (2003b) Tripletransgenic model of Alzheimer's disease with plaques and tangles: intracellular Abeta and synaptic dysfunction. Neuron 39:409-421. Medline

Olsson N, Siegbahn A, Nilsson G (1999) Serum amyloid A induces chemotaxis of human mast cells by activating a pertussis toxin-sensitive signal transduction pathway. Biochem Biophys Res Comm 254:143-146. CrossRef Medline

Orellana JA, Shoji KF, Abudara V, Ezan P, Amigou E, Sáez PJ, Jiang JX, Naus CC, Sáez JC, Giaume C (2011) Amyloid beta-induced death in neurons involves glial and neuronal hemichannels. J Neurosci 31:4962-4977. Medline

Panchin Y, Kelmanson I, Matz M, Lukyanov K, Usman N, Lukyanov S (2000) A ubiquitous family of putative gap junction molecules. Curr Biol 10:R473-R474. Medline

Parekh AB, Putney JW Jr (2005) Store-operated calcium channels. Physiol Rev 85:757-810. CrossRef Medline

Pelegrin P, Surprenant A (2006) Pannexin-1 mediates large pore formation and interleukin-1beta release by the ATP-gated P2X7 receptor. EMBO J 25:5071-5082. CrossRef Medline

Pike CJ, Walencewicz-Wasserman AJ, Kosmoski J, Cribbs DH, Glabe CG, Cotman CW (1995) Structure-activity analyses of beta-amyloid peptides: contributions of the beta 25-35 region to aggregation and neurotoxicity. J Neurochem 64:253-265. Medline

Radde R, Bolmont T, Kaeser SA, Coomaraswamy J, Lindau D, Stoltze L, Calhoun ME, Jäggi F, Wolburg H, Gengler S, Haass C, Ghetti B, Czech C, Hölscher C, Mathews PM, Jucker M (2006) Abeta42-driven cerebral amyloidosis in transgenic mice reveals early and robust pathology. EMBO Rep 7:940-946. CrossRef Medline

Riquelme MA, Cea LA, Vega JL, Boric MP, Monyer H, Bennett MV, Frank M, Willecke K, Sáez JC (2013) The ATP required for potentiation of skeletal muscle contraction is released via pannexin hemichannels. Neuropharmacology 75:594-603. CrossRef Medline

Sáez JC, Retamal MA, Basilio D, Bukauskas FF, Bennett MV (2005) Connexin-based gap junction hemichannels: gating mechanisms. Biochim Biophys Acta 1711:215-224. Medline

Sánchez HA, Orellana JA, Verselis VK, Sáez JC (2009) Metabolic inhibition increases activity of connexin-32 hemichannels permeable to $\mathrm{Ca} 2+$ in transfected HeLa cells. Am J Physiol Cell Physiol 297:C665-C678. CrossRef Medline

Sayed BA, Walker ME, Brown MA (2011) Cutting edge: mast cells regulate disease severity in a relapsing-remitting model of multiple sclerosis. J Immunol 186:3294-3298. CrossRef Medline

Schalper KA, Palacios-Prado N, Orellana JA, Sáez JC (2008) Currently used methods for identification and characterization of hemichannels. Cell Commun Adhes 15:207-218. CrossRef Medline

Schalper KA, Sánchez HA, Lee SC, Altenberg GA, Nathanson MH, Sáez JC (2010) Connexin 43 hemichannels mediate the $\mathrm{Ca} 2+$ influx induced by extracellular alkalinization. Am J Physiol Cell Physiol 299:C1504-C1515. CrossRef Medline

Secor VH, Secor WE, Gutekunst CA, Brown MA (2000) Mast cells are essential for early onset and severe disease in a murine model of multiple sclerosis. J Exp Med 191:813-822. CrossRef Medline

Shanmugam G, Polavarapu PL (2004) Structure of A $\beta(25-35)$ peptide in different environments. Biophys J 87:622-630. CrossRef Medline

Shore PA, Burkhalter A, Cohn VH Jr (1959) A method for the fluorometric assay of histamine in tissues. J Pharmacol Exp Ther 127:182186. Medline

Shukla SA, Veerappan R, Whittimore JS, Ellen Miller L, Youngberg GA (2006) Mast cell ultrastructure and staining in tissue. Methods Mol Biol 315:63-76. Medline

Sick E, Niederhoffer N, Takeda K, Landry Y, Gies JP (2009) Activation of CD47 receptors causes histamine secretion from mast cells. Cell Mol Life Sci 66:1271-1282. CrossRef Medline 
Silver R, Silverman AJ, Vitković L, Lederhendler II (1996) Mast cells in the brain: evidence and functional significance. Trends Neurosci 19:25-31. CrossRef Medline

Silverman WR, de Rivero Vaccari JP, Locovei S, Qiu F, Carlsson SK, Scemes E, Keane RW, Dahl G (2009) The pannexin 1 channel activates the inflammasome in neurons and astrocytes. J Biol Chem 284:18143-18151. CrossRef Medline

Solito E, Sastre M (2012) Microglia function in Alzheimer's disease. Front Pharmacol 3:14. Medline

Sosinsky GE, Boassa D, Dermietzel R, Duffy HS, Laird DW, MacVicar B, Naus CC, Penuela S, Scemes E, Spray DC, Thompson RJ, Zhao HB, Dahl G (2011) Pannexin channels are not gap junction hemichannels. Channels (Austin) 5:193-197. CrossRef Medline

Strbian D, Karjalainen-Lindsberg ML, Tatlisumak T, Lindsberg PJ (2006) Cerebral mast cells regulate early ischemic brain swelling and neutro- phil accumulation. J Cereb Blood Flow Metab 26:605-612. CrossRef Medline

Vanden Abeele F, Bidaux G, Gordienko D, Beck B, Panchin YV, Baranova AV, Ivanov DV, Skryma R, Prevarskaya N (2006) Functional implications of calcium permeability of the channel formed by pannexin 1. J Cell Biol 174:535-546. CrossRef Medline

Vliagoftis H, Hutson AM, Mahmudi-Azer S, Kim H, Rumsaeng V, Oh CK, Moqbel R, Metcalfe DD (1999) Mast cells express connexins on their cytoplasmic membrane. J Allergy Clin Immunol 103:656-662. Medline

Wang J, Ma M, Locovei S, Keane RW, Dahl G (2007) Modulation of membrane channel currents by gap junction protein mimetic peptides: size matters. Am J Physiol Cell Physiol 293:C1112-C1119. CrossRef Medline

Wisniewski HM, Wegiel J, Wang KC, Kujawa M, Lach B (1989) Ultrastructural studies of the cells forming amyloid fibers in classical plaques. Can J Neurol Sci 16:535-542. Medline 